Religious Accommodation, the Establishment Clause, and ThirdParty Harm

Mark Storslee 


\title{
Religious Accommodation, the Establishment Clause, and Third-Party Harm
}

\author{
Mark Storslee $\dagger$
}

In the wake of Burwell v Hobby Lobby, religious accommodation has become increasingly controversial. That controversy has given rise to a new legal theory gaining popularity among academics and possibly a few Supreme Court justices: the idea that the First Amendment's Establishment Clause condemns accommodations whenever they generate anything beyond a minimal cost for third parties.

The third-party thesis is appealing. But this Article argues that there are good reasons to believe it fails as an interpretation of the Establishment Clause. In its place, the Article offers a new theory for understanding the relationship between costly accommodations and the Establishment Clause. That theory begins with a simple assertion: the Establishment Clause is not a prohibition on generic harm but instead a ban on government attempts to promote a favored religious identity. Thus, the fundamental inquiry is not whether a private party bears some cost but instead whether the government is using its power to foster religious conformity.

Although largely overlooked in the literature, members of the Founding generation actually did equate accommodations with establishments on at least two occasions, both involving instances in which accommodations encouraged religious conformity. And as it turns out, the principles drawn from those incidents provide powerful explanations for many of the Court's modern precedents-often more powerful than the Court's own reasoning. But even more, viewing the Establishment Clause as a ban on government attempts to induce religious conformity also offers a more plausible way of thinking about the occasional costs of accommodation. This approach will be more deferential to legislative judgments than an approach focused squarely on harm. But that is not a reason for rejecting it, especially when the limits it provides have proven fairly reliable in dealing with the problem.

$\dagger$ Executive Director, Stanford Constitutional Law Center. Thanks to Stephanie Barclay, William Baude, Thomas Berg, Samuel Bray, Jud Campbell, Nathan Chapman, Nora Freeman Engstrom, Carl Esbeck, Richard Garnett, Stephanie Inks, Mark Kelman, Andrew Koppelman, Douglas Laycock, Christopher Lund, Ira Lupu, William Marshall, Michael McConnell, Chloe Moon, Douglas NeJaime, Jane Schacter, Geoffrey Sigalet, Lance Sorenson, Charles Tyler, Robin Fretwell Wilson, and participants in the Stanford Law School Fellows Workshop and the Annual Law and Religion Roundtable for helpful conversations and feedback on earlier drafts. Special thanks are also due to Frederick Mark Gedicks, Micah Schwartzman, and Nelson Tebbe for their generosity and for helpful conversations about this topic and others. All errors, of course, are my own. 


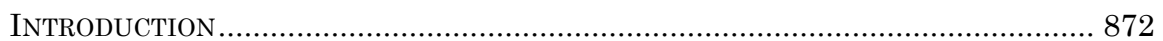

I. Current LaW and Establishment Clause Basics.................................. 880

II. The ThIRD-PARTY Thesis ...................................................................... 883

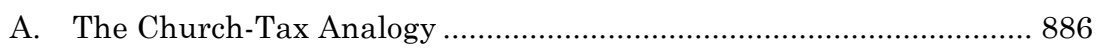

B. The Court's Precedent ......................................................................... 893

1. The religious institution cases............................................... 895

2. The religious conduct cases................................................... 898

III. Limiting ReLigious Accommodation .................................................. 901

A. Against Religious Conformity ...................................................... 902

1. Virginia's General Assessment .................................................. 907

2. The Uniform Militia Act.................................................. 911

B. Modern Doctrine ....................................................................... 915

1. Selective subsidies for favored religious messages.................... 916

2. Incentives to adopt the accommodated religion...................... 921

IV. RECONSIDERING HARM .................................................................... 929

A. The Establishment Clause ............................................................... 930

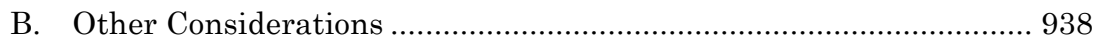

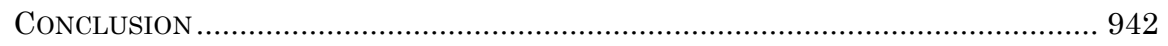

\section{INTRODUCTION}

We occupy a unique moment in the story of American religious liberty. During the Founding period and for much of the twentieth century, it was widely accepted that religious accommodation-the practice of sometimes exempting religious individuals or groups from burdensome laws-was a desirable means of protecting free exercise. ${ }^{1}$ But as a matter of cultural consensus, that agreement seems to be quickly unraveling or at least entering a new period of uncertainty. As Professor Paul Horwitz has observed, "Contestation over religious accommodations has moved rapidly from the background to the foreground," to the point that "[a]ccommodations by anyonecourts or legislatures-have been called into question." 2

1 See, for example, Michael W. McConnell, The Origins and Historical Understanding of Free Exercise of Religion, 103 Harv L Rev 1409, 1466 (1990) (noting that religious accommodations in the Founding period were seen as a "natural and legitimate response to the tension between law and religious convictions"); Philip A. Hamburger, $A$ Constitutional Right of Religious Exemption: An Historical Perspective, 60 Geo Wash L Rev 915, 916-17 (1992) (arguing that the Founding generation did not believe exemptions were constitutionally required, but observing that "many Americans sympathized with their neighbors who had pious scruples about oaths, military service, and a few other legal requirements, and, therefore ... expressly granted religious exemptions").

2 Paul Horwitz, The Hobby Lobby Moment, 128 Harv L Rev 154, 159 (2014). 
Of course, to anyone who reads the news with some regularity, this is no longer a groundbreaking pronouncement. Burwell $v$ Hobby Lobby Stores, Inc ${ }^{3}$ was one of the more controversial cases in recent memory and seriously eroded support for accommodation among many political progressives. ${ }^{4}$ Moreover, many perceive proposals to create or clarify religious accommodation laws at the state level as broadside attacks on LGBTQ rights. ${ }^{5}$ Masterpiece Cakeshop, Ltd $v$ Colorado Civil Rights Commission 6 reinforced that perception, though it did not involve a religious accommodation law as such. Put simply, for a growing number of people, religious accommodation is increasingly reducible to three words: license to discriminate.

The tendency to view religious accommodation primarily in terms of the culture war is understandable. After all, religious liberty cases involving topics like contraception, gay rights, and abortion invariably draw greater media coverage than other disputes and thus play an outsized role in public consciousness. But thinking about accommodation solely or even mostly in terms of the culture war presents some profound dangers.

For one thing, it obscures the significant good that accommodation laws do for religious minorities. In addition to the federal Religious Freedom Restoration Act ${ }^{7}$ (RFRA) and the

3134 S Ct 2751 (2014).

4 The literature either praising or criticizing Hobby Lobby is immense. For a small sampling of some particularly incisive critiques and defenses, compare William P. Marshall, Bad Statutes Make Bad Law: Burwell v Hobby Lobby, 2014 S Ct Rev 71, 105-18 (criticizing the Supreme Court's interpretation of the Religious Freedom Restoration Act (RFRA) in Hobby Lobby); Kent Greenawalt, Hobby Lobby: Its Flawed Interpretive Techniques and Standards of Application, in Micah Schwartzman, Chad Flanders, and Zoë Robinson, eds, The Rise of Corporate Religious Liberty 125, 128 (Oxford 2016) (same), with Douglas Laycock, The Campaign against Religious Liberty, in Schwartzman, Flanders, and Robinson, eds, The Rise of Corporate Religious Liberty 231, 233-38 (defending the Court's decision in Hobby Lobby); Brett H. McDonnell, The Liberal Case for Hobby Lobby, 57 Ariz L Rev 777, 780 (2015) (same); Amy J. Sepinwall, Conscience and Complicity: Assessing Pleas for Religious Exemptions in Hobby Lobby's Wake, 82 U Chi L Rev 1897, 1908-09 (2015) (arguing that Hobby Lobby was rightly decided as a doctrinal matter but questioning certain aspects of the Court's reasoning).

5 See Fernanda Santos, Arizona Governor Vetoes Bill on Refusal of Service to Gays (NY Times, Feb 26, 2014), online at http://www.nytimes.com/2014/02/27/us/Brewerarizona-gay-service-bill.html (visited Nov 19, 2018) (Perma archive unavailable); Campbell Robertson and Richard Pérez-Peña, Bills on 'Religious Freedom' Upset Capitols in Arkansas and Indiana (NY Times, Mar 31, 2015), online at http://www.nytimes.com/2015/04/01/us/religious-freedom-restoration-act-arkansasindiana.html (visited Nov 19, 2018) (Perma archive unavailable).

6138 S Ct 1719 (2018).

7 Pub L No 103-141, 107 Stat 1488 (1993), codified as amended at 42 USC $\S 2000 \mathrm{bb}$ et seq. 
Religious Land Use and Institutionalized Persons Act8 (RLUIPA), there are twenty-one states that have similar general accommodation laws, colloquially known as mini-RFRAs. ${ }^{9}$ Yet the available evidence suggests that the vast majority of claims brought under these laws have nothing to do with topics like contraception, gay rights, or abortion. ${ }^{10}$ They are about hair length, ${ }^{11}$ headgear, ${ }^{12}$ horse-drawn buggies, ${ }^{13}$ beard trimming, ${ }^{14}$ and so on. They are about making allowances for religious diets, ${ }^{15}$ or helping churches obtain suitable real estate, ${ }^{16}$ or allowing small sects to use some banned substance. ${ }^{17}$ The culture war has rendered this universe of cases-and with them, the workaday benefits of accommodation-almost totally invisible.

8 Pub L No 106-274, 114 Stat 803 (2000), codified at 42 USC $\S 2000 c c$ et seq.

9 See State Religious Freedom Restoration Acts (National Conference of State Legislatures, May 4, 2017), archived at http://perma.cc/4TBM-ZJEZ. Fourteen states have adopted standards similar to RFRA when interpreting their state constitutions. See Douglas Laycock, Religious Liberty and the Culture Wars, 2014 U Ill L Rev 839, 844 \& n 22 (collecting citations).

10 See Luke W. Goodrich and Rachel N. Busick, Sex, Drugs, and Eagle Feathers: An Empirical Study of Federal Religious Freedom Cases, 48 Seton Hall L Rev 353, 356, 384 (2018) (conducting an empirical survey of cases in the Tenth Circuit thirty-two months after Hobby Lobby and concluding that there were "no RFRA challenges in the Tenth Circuit to any other medical procedures or drugs" and that "religious minorities are significantly overrepresented in the cases relative to their population"); Stephanie H. Barclay and Mark L. Rienzi, Constitutional Anomalies or As-Applied Challenges? A Defense of Religious Exemptions, 59 BC L Rev 1595, 1634-36 (2018) (noting that an empirical assessment of the federal caseload shows that, even when counting challenges to the "contraception mandate" of the Affordable Care Act separately, such cases made up less than one-third of the total RFRA claims decided in the three years since Hobby Lobby). See also Douglas Laycock, The Wedding-Vendor Cases, 41 Harv J L \& Pub Pol 49, 50-51 (2018) (noting the relatively small number of culture war-related claims at the Supreme Court in free exercise cases decided since 1991).

11 A.A. $v$ Needville Independent School District, 611 F3d 248, 272 (5th Cir 2010) (protecting the right of a kindergartener to wear his hair in accordance with his Native American religious beliefs).

12 Equal Employment Opportunity Commission v Abercrombie \& Fitch Stores, Inc, 135 S Ct 2028, 2034 (2015) (reversing summary judgment granted in favor of an employer who refused to hire a Muslim applicant because she wished to wear a headscarf).

13 State v Hershberger, 462 NW2d 393, 399 (Minn 1990) (protecting the right of the Amish to use horse-drawn buggies without slow-moving-vehicle signage).

14 Holt $v$ Hobbs, $135 \mathrm{~S} \mathrm{Ct}$ 853, 859 (2015) (protecting the right of a Muslim inmate to maintain a half-inch beard).

15 Willis $v$ Commissioner, Indiana Department of Correction, 753 F Supp 2d 768, 782 (SD Ind 2010) (upholding a Jewish prisoner's right to receive kosher meals).

16 Saints Constantine \& Helen Greek Orthodox Church, Inc v City of New Berlin, 396 F3d 895, 901 (7th Cir 2005) (reversing summary judgment forbidding a church from building on a purchased parcel).

17 Gonzales v O Centro Espirita Beneficente Uniao do Vegetal, 546 US 418, 423 (2006) (upholding the right of a Brazilian religious group to use a hallucinogenic tea in its rituals). 
But there is also a deeper problem. Viewing religious accommodation primarily in terms of the culture war has created profound confusion about the meaning of the Establishment Clause. Under statutes like RFRA and RLUIPA, courts are required to deny an accommodation when doing so is the least restrictive means of furthering a compelling interest. ${ }^{18}$ As Justice Anthony Kennedy recently noted, that inquiry necessarily requires courts to consider whether an accommodation "unduly restrict[s] other persons . . in protecting their own interests."19 In the shadow of Hobby Lobby, however, many have begun to argue that the Establishment Clause imposes a much more radical constraint. The proposal has been phrased in different ways and ornamented with different nuances, but we can summarize the position as follows: although legislatures may sometimes provide religious accommodations, the Establishment Clause forbids accommodations whenever they generate more than a minimal cost for "third parties," meaning "persons who ... do not believe or engage in the exempted religious practices." ${ }^{20}$ Let's call this the third-party thesis.

The third-party thesis is appealing because it coheres with a powerful intuition that religion should not be "a license to harm others." ${ }^{21}$ It also offers one possible reading of Supreme Court precedents suggesting that the Establishment Clause somehow limits accommodations that impact nonparticipating citizens. ${ }^{22}$ Thus, it is no wonder that many distinguished scholars are embracing the thesis, ${ }^{23}$ and even a few Supreme Court justices have

1842 USC $\S \S 2000 \mathrm{bb}-1$ (a)-(b), 2000cc-1.

19 Hobby Lobby, $134 \mathrm{~S} \mathrm{Ct}$ at 2787 (Kennedy concurring).

20 Frederick Mark Gedicks and Rebecca G. Van Tassell, Of Burdens and Baselines: Hobby Lobby's Puzzling Footnote 37, in Schwartzman, Flanders, and Robinson, eds, The Rise of Corporate Religious Liberty 323, 323 (cited in note 4).

21 Burt Neuborne, Madison's Music: On Reading the First Amendment 135 (New Press 2015).

22 See generally Estate of Thornton $v$ Caldor, Inc, 472 US 703 (1985); Cutter $v$ Wilkinson, 544 US 709 (2005). See also Part II.B.

23 See, for example, Frederick Mark Gedicks and Rebecca G. Van Tassell, RFRA Exemptions from the Contraception Mandate: An Unconstitutional Accommodation of Religion, 49 Harv CR-CL L Rev 343, 357-59 (2014); Gedicks and Van Tassell, Of Burdens and Baselines at 323-30 (cited in note 20); Nelson Tebbe, Religious Freedom in an Egalitarian Age 49-70 (Harvard 2017); Micah Schwartzman, Richard Schragger, and Nelson Tebbe, The Establishment Clause and the Contraception Mandate (Balkinization, Nov 27, 2013), archived at http://perma.cc/Z33W-DW8T. See also Brief for Amici Curiae Church-State Scholars Frederick Mark Gedicks, Caitlin Borgmann, Caroline Mala Corbin, Steven K. Green, B. Jessie Hill, Richard Schragger, Micah Schwartzman, Elizabeth Sepper, Nelson Tebbe, et al, in Support of the Government, Sebelius v Hobby 
flirted with the idea. ${ }^{24}$ But there is a problem. Put simply, there are good reasons to believe the third-party thesis fails as an interpretation of the Establishment Clause.

At the level of principle, the third-party thesis relies primarily on the claim that costly accommodations "tax" unwilling citizens in ways akin to repressive state churches. But that analogy depends on both a dubious account of history as well as implausible arguments about religious coercion. ${ }^{25}$ Unlike Founding-era church taxes, the purpose and effect of religious accommodation is to leave religion alone, not actively evangelize. Moreover, although accommodations that produce private costs might sometimes create resentment, they do not force anyone to support religion in any way that the law actually recognizes.

Likewise, although the third-party thesis offers a nuanced set of rules for identifying forbidden accommodations, its framework is exceedingly difficult to square with the Court's precedents. ${ }^{26}$ When considering cases involving both religious institutions and the religious conduct of individuals, the Court has repeatedly blessed accommodations that generate costs for others. Indeed, it has sometimes held that the Establishment Clause itself requires them. If the third-party thesis is right, much of our law-including some of the Court's most celebrated religious liberty cases-would seem to be wrong.

This Article offers a new theory for thinking about the relationship between the Establishment Clause and cost-shifting religious accommodations. This theory begins with a simple claim: the Establishment Clause is not a prohibition on harm

Lobby Stores, Inc, Nos 13-354 and 13-356, *13-7 (US filed Jan 28, 2014) (available on Westlaw at 2014 WL 333891) (collecting the support of twenty-one constitutional law scholars in support of the thesis); Hillel Y. Levin, Why Some Religious Accommodations for Mandatory Vaccinations Violate the Establishment Clause, 68 Hastings L J 1193, 1223-41 (2017) (applying a modified version of the third-party thesis to analyze exemptions from vaccination requirements). Likewise, scholars who stop short of fully endorsing the thesis have nonetheless noted its importance. See, for example, Ira C. Lupu, Hobby Lobby and the Dubious Enterprise of Religious Exemptions, 38 Harv J L \& Gender 35, $38 \mathrm{n} 3$ (2015) (referring to the third-party thesis as an "excellent elaboration" of "highly significant" Establishment Clause norms constraining accommodation), citing Gedicks and Van Tassel, 49 Harv CR-CL L Rev at 356-71 (cited in note 23); Douglas NeJaime and Reva B. Siegel, Conscience Wars: Complicity-Based Conscience Claims in Religion and Politics, 124 Yale L J 2516, 2529-33 (2015) (acknowledging the thesis); Richard H. Fallon Jr, Tiers for the Establishment Clause, 166 U Pa L Rev 59, 107-08 (2017) (same).

24 See Holt, $135 \mathrm{~S} \mathrm{Ct}$ at 867 (Ginsburg concurring). See also Part II.

25 See Part II.A.

26 See Part II.B. 
but instead a ban on government attempts to promote a favored religious identity (either a particular religion or religion in general). More specifically, it suggests that, when evaluating the propriety of religious accommodations, the fundamental inquiry is not whether a private party bears some cost but instead whether the government is using its power to foster religious conformity.

Religious accommodations are attempts to protect minorities by making room for religious practices that are unfamiliar to or unaccepted by the majority. Thus, the idea that accommodations can somehow be equated with establishments is largely untenable-accommodations almost always weaken, rather than strengthen, the power of the state to promote a favored orthodoxy. But that is not the whole story. Although often overlooked in the literature on religious accommodation, members of the Founding generation did equate accommodations with establishments on at least two occasions, both of which involved objections that the accommodations encouraged religious conformity. ${ }^{27}$ And reflection on those incidents yields two principal rules for limiting religious accommodations today.

First, the Establishment Clause prohibits accommodations that seek to selectively subsidize the government's preferred religious messages. ${ }^{28}$ Under this rule, although the government may provide accommodations to relieve burdens on religious practice, the Establishment Clause prohibits it from designing those accommodations to offer discriminatory support for the government's preferred religious ideas. So, for example, although the government can make allowances for students in public schools to practice religion by providing release-time for religious instruction, it may not design the accommodation in a way that lends government prestige to the message being spoken while conditioning eligibility on the substance of the religious teaching.

Second, the Establishment Clause prohibits accommodations that provide exceptionally powerful incentives to adopt the religion being accommodated. ${ }^{29}$ Under this rule, when an accommodation operates in ways analogous to a coercive law mandating religious conformity, the Establishment Clause requires that it be struck down or, more likely, modified to dissipate the

\footnotetext{
27 See Part III.A.

28 See Part III.A.1.

29 See Part III.A.2.
} 
incentive. So, for example, when a religious accommodation involves both objectively powerful incentives and widely held claims of conscience-as with exemptions from military service, for instance-there are heightened Establishment Clause concerns over induced conformity that will sometimes require removing or reducing the incentive.

The two limitations described above provide convincing explanations for many of the Court's modern Establishment Clause precedents-in some cases, more convincing than the Court's own reasoning. ${ }^{30}$ But more than this, viewing the Establishment Clause as a ban on government attempts to encourage religious conformity also offers a more plausible way of thinking about the occasional costs of accommodation. Specifically, it clarifies that, although these costs are not themselves a proper basis for an Establishment Clause objection, they can be relevant in determining whether a law is actually a genuine accommodation rather than merely a pretext for rewarding religious conformity. ${ }^{31}$ So, for example, when an accommodation offers gratuitous benefits to religious claimants or transgresses the limits that apply to similar constitutional claims, the Court has been right to suggest that the Establishment Clause is implicated.

To be sure, this approach to the Establishment Clause will be more deferential to legislative judgments than an approach focused squarely on third-party harm. But that is not a reason for rejecting it, especially when other limits have proven fairly reliable in dealing with that problem. For instance, many accommodation laws like RFRA and RLUIPA already contain a balancing test, the primary purpose of which is to safeguard other important interests. ${ }^{32}$ What is more, religious accommodations-like all cost-balancing legislation-are subject to amendment or repeal through the political process. That fact has been important in recent controversies involving religious liberty and LGBTQ rights, in which political majorities have been exceedingly active in shaping or limiting accommodations to protect those interests. A proper understanding of the Establishment Clause does not require ignoring the costs of accommodation. It simply requires that those costs be accounted for more carefully and managed through a variety of means.

\footnotetext{
30 See Part III.B

See Part IV.A.

See Part IV.B.
} 
This Article is organized as follows: Part I explains the basics of the law governing religious accommodation and its relationship to the Establishment Clause. Part II unpacks the problems with viewing the Establishment Clause as a prohibition on generic harm and offers a critique of the third-party thesis. In Part III, the Article offers a new approach for addressing the relationship between cost-shifting accommodations and the Establishment Clause, arguing that the principal inquiry is whether an accommodation has the purpose or effect of fostering religious conformity. This Part discusses some historical incidents often overlooked by scholars to introduce the principles governing the inquiry and goes on to explain their modern doctrinal implications. Finally, Part IV deals with some objections and explores other limits on religious accommodation. This Part begins by explaining the subsidiary role that costs sometimes play in identifying laws that transgress the Establishment Clause. Having done so, it goes on to consider other important limits on religious accommodation, especially those provided by the political process.

Before proceeding to the heart of the argument, however, a few important clarifications are in order. First, in making an argument in favor of the Establishment Clause theory I outline above, this Article deals only with religious accommodations. By "accommodations," I mean laws specifically designed to remove burdens on private religious practice. Those laws take two forms. Most commonly, accommodations provide exemptions from laws that would otherwise burden religiously motivated conduct. Alternatively, they protect free exercise by mandating that employers take reasonable steps to facilitate their employees' religious needs or that the government take steps to allow people in its care to practice their religion. Beyond these categories of laws, this Article makes no specific claims. Thus, although I note that a concern about government-induced conformity runs through the Court's Establishment Clause jurisprudence, I do not attempt to offer a full defense of the principle as applied to other contexts.

Second, in arguing in favor of the Establishment Clause limits I outline above, I have largely set to one side an important additional concern: the requirement that religious accommodations be neutral among religions, or what the Court has 
sometimes called "denominational neutrality." ${ }_{33}$ To be sure, this concern plays some role in considering whether an accommodation selectively favors the government's preferred religious messages. But the prohibition on denominational discrimination also entails additional limitations. ${ }^{34}$ Because these concerns are only tangentially related to the issue of costly accommodations, however, I leave them mostly to the side. A full exploration of the requirement that religious accommodations treat all religions equally will have to be left for another day.

\section{Current LaW And Establishment Clause Basics}

The law of religious accommodation has undergone dramatic change in the last few decades.

For much of the twentieth century, the Supreme Court interpreted the Free Exercise Clause ${ }^{35}$ to require exemptions when a law burdened religiously motivated conduct unless the government could demonstrate that requiring compliance was the least restrictive means of furthering a compelling interest. ${ }^{36}$ In Employment Division, Department of Human Resources of Oregon $v$ Smith, ${ }^{37}$ however, the Court changed course. Specifically, it held that the Constitution does not require heightened scrutiny when a law burdens religious practice so long as the conflict results from a "neutral law of general applicability." 38 The Smith rule has generated significant confusion of its own, but the basic point is this: so long as a law does not treat religious conduct less favorably than analogous secular conduct or contain opportunities for governmental discretion, Smith says the Free Exercise Clause generally does not require exemptions. ${ }^{39}$

33 Larson v Valente, 456 US 228, 246 (1982).

34 For instance, it prohibits a legislature from limiting accommodations out of a desire to exclude a disfavored religious group, even when the accommodation itself is formally neutral. See id at 253-55.

35 US Const Amend I ("Congress shall make no law respecting an establishment of religion, or prohibiting the free exercise thereof.").

36 See Employment Division, Department of Human Resources of Oregon $v$ Smith, 494 US 872, 893 (1990) (O’Connor concurring in the judgment) (explaining the Court's previous free exercise jurisprudence).

37494 US 872 (1990).

38 Id at 879, quoting United States $v$ Lee, 455 US 252, 263 n 3 (1982) (Stevens concurring).

39 For a nice discussion of Smith and its possible meanings, see Douglas Laycock and Steven T. Collis, Generally Applicable Law and the Free Exercise of Religion, 95 Neb L Rev 1, 9-10 (2016). The Court itself has also complicated the Smith rule in ways that remain largely open-ended. See, for example, Hosanna-Tabor Evangelical Lutheran 
Smith radically reduced the scope of protection for religious exercise provided under the Constitution. Yet as the Smith majority made plain, nothing in the ruling meant that such protections were thereby "banished from the political process." 40 On the contrary, in Smith and subsequent cases, the Supreme Court has repeatedly reaffirmed its long-standing view that legislatures may "accommodate religious practices ... without violating the Establishment Clause." 41

Legislatures have responded by enacting or strengthening many different kinds of religious accommodations. Some of these-such as laws allowing groups to use peyote in their religious services ${ }^{42}$ or the clergy-penitent privilege contained in most rules of evidence ${ }^{43}$ - extend protections in specific contexts. But even more important are so-called "general" accommodation laws like RFRA and RLUIPA. ${ }^{44}$ Under those statutes and state laws like them, ${ }^{45}$ when a claimant demonstrates that a law "substantially burden[s]" her religious exercise, the government must grant an exemption unless it can demonstrate that enforcing the law is the least restrictive means of furthering a compelling governmental interest. 46

Accommodations have sometimes been subjected to wholesale Establishment Clause challenges. Yet the Court has repeatedly rebuffed those arguments, and often without a single dissent. As an introductory matter, two of the Court's conclusions are of particular importance.

Church \& School v Equal Employment Opportunity Commission, 565 US 171, 190 (2012) (holding that the Free Exercise Clause prohibits applying employment discrimination laws to claims involving a religious institution and its ministers, and distinguishing Smith as concerning "government regulation of only outward physical acts" rather than "an internal church decision").

40 Smith, 494 US at 890.

41 Cutter $v$ Wilkinson, 544 US 709, 713 (2005), quoting Hobbie v Unemployment Appeals Commission of Florida, 480 US 136, 144-45 (1987).

42 See 42 USC $\S 1996 \mathrm{a}(\mathrm{b})(1)$.

43 See Cox v Miller, 296 F3d 89, 102 (2d Cir 2002) (explaining that "every state has enacted the cleric-congregant privilege in some form").

44 As Professor Kent Greenawalt explains, exemptions may be "specific" by applying to a particular law or "general" by offering a set of standards to a variety of laws. Kent Greenawalt, Exemptions: Necessary, Justified, or Misguided? 9 (Harvard 2016).

45 See note 9; Christopher C. Lund, Religious Liberty after Gonzales: A Look at State RFRAs, 55 SD L Rev 466, 473-79 (2010) (providing a basic overview of state RFRAs).

46 See 42 USC $\S \S 2000 b b-1(a)-(b), 2000 c c-1$. See also Lund, 55 SD L Rev at 475-79 (cited in note 45). 
First, the Court has repeatedly held that religious accommodations do not violate the Establishment Clause merely because they "single[] out religious entities for a benefit." 47 That conclusion flows both from historical practice and from the text of the Constitution itself. Accommodations that single out religious exercise have always been ubiquitous in American law, before as well as after the adoption of the First Amendment.48 Moreover, by its terms the Free Exercise Clause provides religious exercise with special protection not provided to other kinds of commitments. It follows as a matter of course that ordinary legislation adopting a similar approach is permissible under the Constitution. "Where ... government acts with the proper purpose of lifting a regulation that burdens the exercise of religion," the Court has said, "we see no reason to require that the exemption come packaged with benefits to secular entities." 49

Second, religious accommodations do not violate the Establishment Clause merely because they "accommodate religion beyond free exercise requirements." 50 The reason, the Court has explained, stems from the "play in the joints" between the Religion Clauses-a zone of discretion that allows for "state actions permitted by the Establishment Clause but not required by the Free Exercise Clause." ${ }_{11}$ Thus, although accommodations are not usually required by the Constitution after Smith, legislatures may choose to enact them without violating the Establishment Clause.

Of course, saying that religious accommodation is generally permissible under the Establishment Clause is not to say the Constitution provides no limits. That is because, although genuine accommodations cohere with the Constitution, attempts to promote the government's favored religion do not. As the Court has put it, although the Establishment Clause provides "ample room" for religious accommodation, "[a]t some point, accommodation may devolve into 'an unlawful fostering of religion." ${ }_{52}$ In the shadow of Hobby Lobby, however, several scholars have

\footnotetext{
47 Corporation of the Presiding Bishop of the Church of Jesus Christ of Latter-Day Saints v Amos, 483 US 327, 338 (1987). See also Cutter, 544 US at 724.

48 See Horwitz, 128 Harv L Rev at 167 (cited in note 2) ("Accommodation of religion is an aboriginal feature of American public law."). See also notes 169-71 and accompanying text (describing several religious accommodations during the Founding period).

49 Amos, 483 US at 338.

50 Cutter, 544 US at 713

51 Locke v Davey, 540 US 712, 718-19 (2004).

52 Amos, 483 US at 334-35, quoting Hobbie, 480 US at 145.
} 
begun to suggest that the Establishment Clause imposes a much more stringent constraint. It is that theory, which I call the third-party thesis, that this Article turns to next.

\section{THE THIRD-PARTY THESIS}

The crux of the third-party thesis can be stated simply: although religious believers (the "first" party) may sometimes receive exemptions from government (the "second" party), the Establishment Clause forbids accommodations that generate costs or burdens for "third parties," meaning "persons who derive no benefit from an exemption because they do not believe or engage in the exempted religious practices." 53 Thus, the argument goes, although accommodations are sometimes permissible, the Establishment Clause condemns accommodations that "shift the costs" associated with an underlying activity from "one private citizen onto another private citizen," at least when those costs are more than negligible. ${ }^{54}$

The third-party thesis is an attractive theory, not least because it draws on a widely shared intuition that religion should not be a "license to harm others." 55 And of course, that intuition is true as far as it goes. To state the obvious, no one thinks that religious believers or anyone else have the right to engage in murder, theft, or trespass. Yet the third-party thesis goes much further by suggesting that accommodations are constitutionally prohibited when they alter the distribution of private burdens in much less radical ways. ${ }^{56}$ In the wake of Hobby Lobby, that view

53 Gedicks and Van Tassell, Of Burdens and Baselines at 323 (cited in note 20).

54 Tebbe, Religious Freedom in an Egalitarian Age at 50 (cited in note 23). Supporters of the third-party thesis claim that their rule is also grounded in free exercise, yet the specifics of their arguments differ. Professor Frederick Gedicks and Rebecca G. Van Tassell rest their assertion mostly on the claim that the Court has sometimes included dicta about harms to others in free exercise cases. See Gedicks and Van Tassell, Of Burdens and Baselines at 326 (cited in note 20) (arguing that two of the Court's "free exercise decisions" have denied exemptions based on concerns over third-party burdens). By contrast, Professor Nelson Tebbe asserts that "the Free Exercise Clause itself . . . incorporate[s] the imperative of avoiding harm to others." Tebbe, Religious Freedom in an Egalitarian Age at 59 (cited in note 23). In both accounts, however, the crucial claim is that costly accommodations "impose" one citizen's faith on another. See id at 58, quoting United States v Lee, 455 US 252, 261 (1982); Gedicks and Van Tassell, Of Burdens and Baselines at 325 (cited in note 20). Because the Establishment Clause already prohibits impositions of religion, however, this Article deals with those arguments in that context. See Part II.A.

55 Neuborne, Madison's Music at 135 (cited in note 21).

56 See text accompanying notes 114-18 (discussing the proposed thresholds to trigger an Establishment Clause objection under the third-party thesis). 
has attracted support from a number of distinguished legal academics. ${ }^{57}$ But even more importantly, it is also beginning to gather at least tepid support among some members of the Supreme Court. 58

In Holt $v$ Hobbs, ${ }^{59}$ the Supreme Court unanimously held that a Muslim inmate seeking to grow a half-inch beard was entitled to an exemption under RLUIPA from a prison grooming policy. ${ }^{60}$ In a brief concurrence joined by Justice Sonia Sotomayor, Justice Ruth Bader Ginsburg stated that she joined the Court's opinion because, "[u]nlike the exemption this Court approved in ... Hobby Lobby, accommodating [the prisoner's] religious belief ... would not detrimentally affect others who do not share petitioner's belief."61 Justice Ginsburg did not explicitly mention the Establishment Clause in Holt. Yet her citations suggest that she may have been relying on the clause as the basis for her view. ${ }^{6}$

In at least one important sense, Justice Ginsburg's concurrence in Holt makes a valid point. In holding that religious businesses and their owners were entitled to an exemption from the "contraceptive mandate" under RFRA, the Hobby Lobby majority asserted that the cost to Hobby Lobby's employees would be "precisely zero" because they could receive contraceptives directly from the government.63 But that assertion skated over the fact that many women were left without contraceptive coverage while the agency created an alternative program to deliver it. ${ }^{64}$ It must be said that the gap in coverage was not the Court's

57 See note 23 and accompanying text.

58 See note 24 and accompanying text.

59135 S Ct 853 (2015).

60 Id at 859.

61 Id at 867 (Ginsburg concurring).

62 See id (Ginsburg concurring). See also Hobby Lobby, $134 \mathrm{~S} \mathrm{Ct}$ at 2790 \& n 8 (Ginsburg dissenting) (citing several Establishment Clause precedents to argue that "[a]ccommodations to religious beliefs or observances . . . must not significantly impinge on the interests of third parties"); id at 2801 (pointing out that the Court has said that the Establishment Clause requires courts to "take adequate account of the burdens a requested accommodation may impose on nonbeneficiaries") (quotation marks and citation omitted). Admittedly, not everyone reads Justice Ginsburg's statement in Holt as linked to the Establishment Clause. For an alternative view, see Kevin C. Walsh, Did Justice Ginsburg Endorse the Establishment Clause Third-Party Burdens Argument in Holt v. Hobbs? (Mirror of Justice, Jan 21, 2015), archived at http://perma.cc/8P63-DJM6.

63 Hobby Lobby, $134 \mathrm{~S} \mathrm{Ct}$ at 2760.

64 For elaboration on this point, see Tebbe, Religious Freedom in an Egalitarian Age at 67-70 (cited in note 23). 
fault. But it is nonetheless true that the Hobby Lobby majority understated the costs of its ruling.

At the same time, there is also reason for caution. Justice Ginsburg's concurrence in Holt-like the academic argument in favor of the third-party thesis-proposes an aggressive Establishment Clause limit on religious accommodation as a direct response to Hobby Lobby. Yet as Professor Christopher Lund has noted, Hobby Lobby was an outlier. ${ }^{65}$ Most religious accommodation cases have nothing to do with topics like abortion or contraception. They are about things like protecting the right of the Amish to use buggies without signage, ${ }^{66}$ protecting the right of Native American and Muslim individuals to wear their hair or beards in accordance with their religion, ${ }^{67}$ protecting the right of churches to maintain their ministries in the face of onerous zoning regulations, ${ }^{68}$ and allowing clergy to maintain their confidences in the face of subpoenas. ${ }^{69}$ And when one considers that larger world of cases, the idea that the Constitution prohibits any accommodation that "detrimentally affects others" becomes exceedingly difficult to sustain.

Consider just a few examples. Laws regulating zoning protect the property values of specific homeowners. But they also regularly prohibit churches or mosques from carrying on their ministries, and especially from providing services to the homeless. ${ }^{70}$ Are exemptions from such laws, which RLUIPA regularly requires, now an Establishment Clause violation because they adversely affect neighborhood traffic flows or home values? Likewise, laws regulating animal slaughter instantiate the values of animal rights groups who believe certain practices are inhumane or environmentally irresponsible. Yet without specific exemptions, those laws conflict with the kosher requirements of

65 Christopher C. Lund, Keeping Hobby Lobby in Perspective, in Schwartzman, Flanders, and Robinson, eds, The Rise of Corporate Religious Liberty 285, 288-89 (cited in note 4) (observing that Hobby Lobby and other culture war cases are "highly unrepresentative" yet are "driving the discussion on both the left and the right").

66 State v Hershberger, 462 NW2d 393, 399 (Minn 1990).

67 A.A. $v$ Needville Independent School District, 611 F3d 248, 253 (5th Cir 2010) (protecting the right of a Native American kindergartener to wear his hair in accordance with his religious beliefs); Holt, $135 \mathrm{~S} \mathrm{Ct}$ at 859 (protecting the right of a Muslim inmate to maintain a half-inch beard).

68 Chosen 300 Ministries, Inc v City of Philadelphia, 2012 WL 3235317, *26-27 (ED

$\mathrm{Pa}$ ) (allowing a church to continue its homeless ministry in the face of zoning challenges). 69 Mockaitis v Harcleroad, 104 F3d 1522, 1530 (9th Cir 1997).

70 See, for example, United States $v$ County of Culpeper, 245 F Supp 3d 758, 769 (WD Va 2017); Chosen 300 Ministries, 2012 WL 3235317 at *26-27. 
many observant Jewish communities. Are exemptions from such laws-which have been recognized and praised by the Supreme Court71_actually unconstitutional? What about religious exemptions from the Americans with Disabilities Act?72 From the Copyright Act? ${ }^{73}$ From the Fair Housing Act?74 The list goes on and on.

To be sure, Justice Ginsburg probably did not have all these laws in mind when she penned her concurrence in Holt. But that is precisely the point. The argument that the Establishment Clause forbids any accommodation that "detrimentally affects others" might sound appealing when we are thinking only about Hobby Lobby. But when we widen the frame even slightly, it becomes apparent that such a rule would require a full-scale revolution in our law.

Of course, revolution might not be a bad thing. If the thirdparty thesis is a correct interpretation of the Establishment Clause, as several scholars now contend, such a change is long overdue. Thus, it is worth considering the arguments for the third-party thesis in more detail.

\section{A. The Church-Tax Analogy}

At the level of Establishment Clause principle, the most prominent argument in favor of the third-party thesis relies on an analogy to mandatory tax support for churches. Specifically, proponents argue that religious accommodations violate the Establishment Clause whenever they shift burdens to others because such burdens "function[] as a tax on nonadherents to support someone else's religious beliefs." 75 So for example,

71 See Church of the Lukumi Babalu Aye, Inc v City of Hialeah, 508 US 520, 539 (1993), citing 7 USC § 1902(b).

72 Pub L No 101-336 §307, 104 Stat 363 (1990), codified at 42 USC $\S 12187$.

73 Pub L No 94-553 §101, 90 Stat 2549 (1976), codified as amended at 17 USC $\S 110(3)$.

74 Pub L No 90-284 $\S 807,82$ Stat 84 (1968), codified as amended at 42 USC $\S 3607(\mathrm{a})$.

75 Gedicks and Van Tassell, Of Burdens and Baselines at 334 (cited in note 20). See also Tebbe, Religious Freedom in an Egalitarian Age at 52 (cited in note 23) (arguing that opposition to religious taxes indicates that "the founding generation ... committed themselves to the idea that the costs of accommodating the faith of some citizens should not be imposed on citizens of other faiths or no faith"). The original version of this argument appeared in Ira C. Lupu, Reconstructing the Establishment Clause: The Case against Discretionary Accommodation of Religion, 140 U Pa L Rev 555, 593 (1991) (suggesting that accommodations involving costs can sometimes be analogized to "coercive taxation to support the religious practices of others"). 
whenever an accommodation requires "the denial of employee entitlements and protections to facilitate an employer's practice of religion, this denial functions as a tax on employees to support the employer's religion.” 76

On a first read, the church-tax analogy is fairly convincing. Most obviously, it identifies an aversion to "paying for religion" that is common among some citizens, and it transforms that aversion into a legal argument by drawing an analogy between accommodation and a practice that virtually everyone agrees is unconstitutional. But on closer examination, the analogy between church taxes and accommodation is superficial. The purpose and effect of religious accommodation is to leave religion alone or, more specifically, to avoid impinging on free exercise by removing legal impediments or combatting private discrimination. In church-tax schemes, by contrast, the government uses its power not to protect religious freedom but instead to actively evangelize. ${ }^{77}$ And it was that fact-not the bare association of religion and unwanted cost-that motivated historical objections to religious taxes.

To illustrate the point, consider the debate over Virginia's General Assessment. In the wake of American independence, members of the Virginia legislature proposed a tax on citizens to support clergy members of their choosing or educational institutions within the commonwealth. ${ }^{78}$ Opposing the assessment, supporters of religious liberty such as James Madison argued that requiring even "three pence" for support of a minister was indistinguishable from full-blown religious establishment.79 But that argument was not based on the idea that any undesired cost associated with religion should be prohibited. Instead, Madison's argument was much simpler. Tax-support schemes were objectionable because they effectively deprived all citizens-those who gave to churches willingly and those who did

76 Gedicks and Van Tassell, Of Burdens and Baselines at 335 (cited in note 20).

77 See Thomas C. Berg, Religious Accommodation and the Welfare State, 38 Harv J L \& Gender 103, 145 (2015) (noting that laws requiring church attendance and tax support involved "compulsion to engage in a religious practice" and "remove[d] no legal burden on [any] faith and thus serve[d] no free exercise interest").

78 A Bill "Establishing a Provision for Teachers of the Christian Religion," 1784, Virginia House of Delegates (Dec 24, 1784), reprinted in Thomas E. Buckley, S.J., Church and State in Revolutionary Virginia, 1776-1787 188 (Virginia 1977).

79 James Madison, To the Honorable General Assembly of the Commonwealth of Virginia: A Memorial and Remonstrance (1785), reprinted in Robert S. Alley, ed, James Madison on Religious Liberty 55, 57 (Prometheus 1985). 
not-of the freedom to "render to the Creator such homage and such only as [they] believe[d] to be acceptable to him." ${ }^{0}$ In other words, religious taxes were equivalent to establishment not because they forced some people to pay for religion they did not like but because they effectively forced everyone to engage in a religious observance-namely, tithing. ${ }^{81}$ Taxing people solely to support the religious functions of churches is no different from coerced worship. But no one in the Founding generation ever so much as hinted that this problem had anything to do with religious accommodations.

Of course, one possible response is to concede the historical point but argue that costly accommodations infringe on liberty in an analogous way. And indeed, supporters of the third-party thesis have suggested as much by arguing that accommodations generating costs "compel[] citizens ... to support an article or manifestation of faith." 82 Here too, however, it is worth drilling down. Proponents of the thesis tend to be vague about how the costs of some accommodations coerce others to "support" an article of religious faith. But the claim seems to imply two possibilities: either these costs are a forced religious observance or they are compelled speech. Yet like the historical claim, both of these arguments become problematic on closer examination.

As we have already observed, forced payment to support a minister is a religious observance in the most literal sense-it is a tithe. But that is simply not the case for the incidental costs associated with religious accommodation. Granting a church an exemption from zoning laws might have a detrimental effect on home values or traffic flows, but it is a far cry from forcing anyone to practice a religion. Protecting a religious employee who wishes to attend a worship service might increase the cost of running a business, but it doesn't require anyone to observe a

80 Id at 56 .

81 As part of that argument, Madison also denied that the law actually allowed individuals to avoid giving to a church by giving their money to education. See id at 56 . Again, however, Madison's argument was that the assessment denied non-Christians the "equal freedom" to refrain from worshipping. Id at 57. In Madison's words, it forced them to "embrace, to profess and to observe" the Christian religion, presumably because even Virginia's seminaries of learning possessed ecclesial ties. Id at 57. See also Frederick Rudolph, The American College and University: A History 16 (Georgia 1962) (observing that the president of the College of William and Mary was a representative of the Bishop of London and head of the Anglican Church of Virginia).

82 Tebbe, Religious Freedom in an Egalitarian Age at 54 (cited in note 23). See also Gedicks and Van Tassell, 49 Harv CR-CL L Rev at 363 (cited in note 23). 
Sabbath. In these circumstances and others, a secular cost or burden is just that.

The argument about subsidized speech fares no better, though it probably lies closest to the heart of the church-tax analogy. ${ }^{83}$ Under the Court's precedents, government is sometimes forbidden from forcing private individuals to "fund[] [] the speech of other private speakers or groups." 84 So for instance, individuals cannot be forced to pay for the speech of unions or for private advertising with which they disagree. ${ }^{85}$ In those cases, however, government is directly coercing one party to redistribute resources to another with the purpose of facilitating the latter's expression. A law requiring public sector employees to pay for a union's speech forcibly transfers wealth from the former to the latter, 86 a law requiring lawyers to fund the ideological messages of bar associations takes money out of their pockets and puts it in the associations' coffers, ${ }^{87}$ and so on. But when we are talking about the incidental costs of protecting rights, things are very different.

Think about just a few examples from the free speech context. Upholding a Nazi's right to march in Skokie ${ }^{88}$ may be controversial, but no one thinks that, by doing so, the Supreme Court embraced a fascist ideology or required the citizens of Illinois to do so. Likewise, requiring a particular community to pay for increased police presence at a white supremacist rallywhich the First Amendment does ${ }^{89}$-will undoubtedly be unpopular. But we would never say that the First Amendment is "taxing" citizens to support the $\mathrm{Ku}$ Klux Klan. The First Amendment allows hate groups to protest at military funerals, but we do not think that means government has coerced attendees to "support" such speech.90 The reason for all these

83 See Micah Schwartzman, Nelson Tebbe, and Richard Schragger, The Costs of Conscience, 106 Ky L J 781, 787 \& n 21 (2017-2018) (citing the Supreme Court's compelled subsidy precedents to argue that, "when [ ] costs fall on a discrete group of citizens, they can rightly complain that they are being coerced as a matter of conscience").

84 Knox $v$ Service Employees International Union, Local 1000, 567 US 298, 309 (2012), citing Abood v Detroit Board of Education, 431 US 209, 222-23 (1977).

85 See Janus $v$ American Federation of State, County \& Municipal Employees, Council 31, 138 S Ct 2448, 2460 (2018). See also United States v United Foods, Inc, 533 US 405, 413 (2001).

86 See Janus, $138 \mathrm{~S}$ Ct at 2464

87 See Keller v State Bar of California, 496 US 1, 13-14 (1990).

88 See National Socialist Party of America v Village of Skokie, 432 US 43, 44 (1977).

89 See Forsyth County $v$ Nationalist Movement, 505 US 123, 133 (1992).

90 See Snyder v Phelps, 562 US 443, 460 (2011). 
judgments is simple: in all these instances, although the costs associated with speech may generate frustration, they do not actually impinge on anyone's right to refrain from speaking. The costs are ancillary to the protection of a freedom, not the product of a law compelling redistribution to pay for speech. ${ }^{91}$

What is true of traditional free speech cases is also true of costly religious accommodations. Like protecting Nazi speech or funeral protesters, protecting someone else's ability to practice her religion may sometimes be detested or even abhorred, especially when it entails costs. But in those instances-as in most free speech cases-the costs generated are purely incidental. A zoning accommodation for a mosque might impact a particular homeowner, but it doesn't command a monetary transfer from one speaker to another. An accommodation requiring a private employer to accommodate her employee's religious needs might invoke resentment. But it doesn't require her to pay her employee for religious speech; it merely requires that she adjust workplace rules to account for things like religious dress or Sabbath observance. Those kinds of incidental costs do not force anyone to endorse a religion. They are simply part of the cost we all sometimes bear in a republic in which many sorts of freedom are prized and valued. ${ }^{92}$

Like the historical claim, then, the arguments about religious coercion underlying the church-tax analogy sound plausible. But on further inspection, they also lack any real grounding. Although accommodations carrying costs sometimes generate resentment, they simply do not require anyone to "support" religion in any way that the law actually recognizes.

But is there yet another way to understand the church-tax analogy? As an add-on to their arguments about religious coercion, supporters of the third-party thesis have sometimes suggested that costly accommodations violate the Establishment

91 Direct government coercion requiring one speaker to subsidize another's expression is an essential element of any subsidized speech case. See Micah Schwartzman, Conscience, Speech, and Money, $97 \mathrm{Va}$ L Rev 317, 380 (2011) (observing that the "general logic of compelled support doctrine" begins with the claim that "government cannot force people to speak" and subsequently asserts that "financial contributions for expressive purposes are treated either as intrinsically expressive or as facilitating expression"). See also Wesley J. Campbell, Speech-Facilitating Conduct, 68 Stan L Rev 1, 37 (2016) (arguing that the logic of the Court's compelled speech precedents involves asking "whether a compelled subsidy exacts a disproportionate sum for speech activities in light of any nonspeech purposes").

92 For an elegant explanation of this point, see Richard W. Garnett, Accommodation, Establishment, and Freedom of Religion, 67 Vand L Rev En Banc 39, 48-49 (2014). 
Clause by fostering "unequal citizenship" on the basis of religion. ${ }^{93}$ According to this argument, "When one group is 'taxed' so that another group may be accommodated in their observance, citizens are stratified on the basis of belief." 94

As a matter of course, government may not punish or otherwise discriminate against citizens on the basis of their religion. To cite just one paradigmatic example, government may no more forbid a minister from holding elected office than it may prohibit an atheist from doing so. ${ }^{95}$ But it is doubtful that religious accommodations-even those that inadvertently generate costs for others-transgress this principle. We do not think that the government is stratifying according to sex when it accommodates pregnant women or commands private employers to do so. ${ }^{96}$ Nor do we think that government is fostering unequal citizenship in favor of individuals with disabilities when it requires accommodations under the Americans with Disabilities Act.97 Rather, the government is simply choosing to defend groups or activities that may be underprotected through free-market mechanisms. If the legislature adds a religious accommodation alongside these others, the inference of protection-notstratification would seem to be no different, even if the accommodation-like these others-generates costs.

To be sure, one might respond by suggesting that, unlike these other categories, religion is especially dangerous and politically divisive. ${ }^{98}$ That intuition was the one that fueled some versions of Justice Sandra Day O'Connor's endorsement test and its suggestion that the Establishment Clause prohibits "send[ing] a message to nonadherents that they are outsiders, not full members of the political community" and vice-versa. ${ }^{99}$ But there is a problem here too. As even some supporters of the third-party

93 Tebbe, Religious Freedom in an Egalitarian Age at 54 (cited in note 23).

94 Schwartzman, Tebbe, and Schragger, $106 \mathrm{Ky} \mathrm{L} \mathrm{J} \mathrm{at} 787$ (cited in note 83).

95 See McDaniel $v$ Paty, 435 US 618, 629 (1978) (holding that a state law barring ministers from serving as delegates to a state constitutional convention violated the Free Exercise Clause); Torcaso $v$ Watkins, 367 US 488, 496 (1961) (holding that a state constitutional provision requiring public officials to declare their belief in the existence of God violated the First Amendment).

96 See Pregnancy Discrimination Act, Pub L No 95-555, 92 Stat 2706 (1978), codified at 42 USC $\S 2000 \mathrm{e}(\mathrm{k})$.

97104 Stat 327, 42 USC § $12112(\mathrm{a})-(\mathrm{b})$.

98 See Tebbe, Religious Freedom in an Egalitarian Age at 54 (cited in note 23) (arguing that costly accommodations are especially objectionable because they risk "dividing and stratifying the political community along religious lines").

99 Lynch v Donnelly, 465 US 668, 688 (1984) (O’Connor concurring). 
thesis have recognized, an Establishment Clause rule focused on division and alienation is unworkable as a basis for constitutional decision-making. ${ }^{100}$ In a democracy in which majorities set the order of the day, it is all but inevitable that those in the minority will sometimes feel like outsiders. What is more, alienation and division seem inescapable when it comes to religion in particular. The Court's School Prayer Cases undoubtedly protected religious liberty, but they also alienated those who believe that government-sponsored prayer or Bible reading are important features of public education. ${ }^{101}$ Rightly understood, a concern over government endorsement of particular religious views has merit. But the idea that we can build Establishment Clause jurisprudence around avoiding strife-and especially strife around religion-seems highly implausible.

But for the sake of argument, let's entertain the idea. Even assuming a focus on alienation represents a workable method of constitutional adjudication, the argument derived from political divisiveness is at best indeterminate when applied to costshifting accommodations. Indeed, there is good reason to think it cuts in favor of such accommodations, not against them.

Critics emphasizing "religious stratification" or "unequal citizenship" highlight the perspective of a private party who bears some cost as a result of an accommodation. ${ }^{102}$ But why should we privilege that perspective? As already noted, in the post-New Deal world, government can and does redistribute costs to accommodate a variety of important interests: pregnancy, disability, and many others. And judged against this backdrop, the idea that it may never offer such protections to religious interests solely because they are religious does not avoid division. It

100 See, for example, Andrew Koppelman, Defending American Religious Neutrality 47 (Harvard 2013) (critiquing this version of the endorsement test on the grounds that "political division is an unavoidable part of life in a democracy"). See also Richard W. Garnett, Religion, Division, and the First Amendment, 94 Georgetown L J 1667, 1723-24 (2006) (providing the canonical version of this critique).

101 See School District of Abington Township v Schempp, 374 US 203, 223 (1963); Engel $v$ Vitale, 370 US 421, 424 (1962). For a critique of the Court's School Prayer Cases along these lines, see Steven D. Smith, The Rise and Decline of American Religious Freedom 131 (Harvard 2014) (observing that prohibiting school prayer necessarily "reject[ed] the views of citizens who believe on religious grounds that school prayer is desirable or obligatory"). There is no doubt that Justice O'Connor's endorsement test condemns laws that alienate religious adherents just as much as those that alienate nonadherents. See Lynch, 465 US at 688 (O'Connor concurring) (noting that the test condemns "government endorsement or disapproval of religion") (emphasis added).

102 See, for example, Tebbe, Religious Freedom in an Egalitarian Age at 54 (cited in note 23$)$. 
exacerbates it. Justice William Brennan memorably observed that "[t]he Establishment Clause does not license government to treat religion and those who teach or practice it, simply by virtue of their status as such, as subversive of American ideals and therefore subject to unique disabilities." 103 Singling out religion for special exclusion might strike some as enforcing equality. But it could just as well be-and increasingly is-considered evidence of outright hostility. ${ }^{104}$ Moreover, religious accommodation itself is designed to reduce social conflict by defusing clashes between government regulation and religious practice in situations in which the government's interests can yield. To the extent that the church-tax analogy depends on arguments about "divisiveness" or "stratification," it is a weak reason for revolutionizing our law.

\section{B. The Court's Precedent}

There are good reasons to question whether the third-party thesis rests on a sound Establishment Clause theory. But even setting that point aside, it still remains to be seen whether the thesis is viable under the Court's precedent.

Proponents of the third-party thesis rely primarily on two precedents as the basis for their theory. The first is Estate of Thornton $v$ Caldor. ${ }^{105}$ In Caldor, the Supreme Court struck down a Connecticut law declaring that no employee could be required to work on a day that her religious tradition observed as a Sabbath. ${ }^{106}$ Writing for the Court, Chief Justice Warren Burger concluded that the law violated the Establishment Clause because of its "unyielding weighting in favor of Sabbath observers." 107 According to Chief Justice Burger, the statute improperly mandated that "Sabbath religious concerns automatically

103 McDaniel, 435 US at 641 (Brennan concurring in the judgment).

104 See, for example, Trinity Lutheran Church of Columbia, Inc $v$ Comer, $137 \mathrm{~S} \mathrm{Ct}$ 2012, 2025 (2017) (concluding that excluding a church from "a public benefit for which it is otherwise qualified, solely because it is a church, is odious to our Constitution ... and cannot stand"). See also id at 2027 (Breyer concurring) (explaining that the Constitution forbids government from excluding churches from "participation in a general program designed to secure or to improve the health and safety of children" when "[t]he sole reason [ ] that explains the difference is faith").

105472 US 703 (1985).

106 Id at $710-11$.

107 Id at 710 . 
control over all secular interests" and risked placing "significant burdens" on employers and other employees. ${ }^{108}$

The second precedent is Cutter $v$ Wilkinson. ${ }^{109}$ In Cutter, the Court unanimously concluded that RLUIPA, the accommodation applying to prisons, ${ }^{110}$ was permissible under the Establishment Clause. The Court reiterated its broad view that "government [may] accommodate religion beyond free exercise requirements, without offense to the Establishment Clause."111 In so holding, the Court reasoned that RLUIPA complied with the Establishment Clause in part because the statute requires courts to "take adequate account of the burdens a[n] [] accommodation may impose on nonbeneficiaries." ${ }_{112}$ Citing Caldor, the Court declared that "an accommodation must be measured so that it does not override other significant interests." 113

As should be apparent, Caldor and Cutter fall far short of offering an unambiguous pronouncement on the meaning of the Establishment Clause, much less a declaration about thirdparty harm as a core principle. But proponents of the thesis have offered three criteria to transform the language of these cases into a workable Establishment Clause test.

First, they insist that the Establishment Clause is violated only when an accommodation "shift[s] meaningful harms to identifiable others" as opposed to merely creating a cost for the public at large. ${ }^{114}$ So, for example, an accommodation for Sabbath observers that requires the government to pay additional unemployment benefits would not violate the Establishment Clause, but one that required specific employers to incur the same cost would. Let's call this the redistribution requirement.

Second, they assert that their Establishment Clause limit does not apply when "a preexisting burden on third parties [i]s marginally increased" as a result of an accommodation. ${ }^{115}$ So, for example, although draft exemptions for religious objectors have

108 Id at 709-10.

109544 US 709 (2005).

110 See text accompanying note 59-60.

111 Cutter, 544 US at 713.

112 Id at 720 .

113 Id at 722, citing Caldor, 472 US at 709-10.

114 Tebbe, Religious Freedom in an Egalitarian Age at 55 (cited in note 23). See also Frederick Mark Gedicks and Andrew Koppelman, Invisible Women: Why an Exemption for Hobby Lobby Would Violate the Establishment Clause, 67 Vand L Rev En Banc 51, 56 (2014) (arguing that accommodations that "increase [] the pre-existing tax burden" differ from those that inadvertently shift costs to "a limited, narrow, and discrete class").

115 Gedicks and Van Tassell, 49 Harv CR-CL L Rev at 363 (cited in note 23). 
sometimes been thought to impose significant burdens on others, supporters of the third-party thesis reject this argument because "all potential draftees were already subject to a substantial risk of being drafted," and the causal connection between exempting one person and drafting another is simply too attenuated. ${ }^{116}$ Let's call this the causation requirement.

Third, supporters of the thesis argue that their Establishment Clause rule does not apply when costs or burdens on others fall below a minimal threshold. Some claim that the Establishment Clause prohibits any accommodation that imposes a "material" burden on others, meaning a burden that is "relevant to [] decisions about how to act in some relevant way." 117 Others insist that the proper inquiry is whether an accommodation imposes an "undue hardship" on others, by which they mean a burden that is "more than [] de minimis."118 In either case, the point is the same: the Establishment Clause is triggered only when the burdens shifted to others cross a fairly low bar. Let's call this the weightiness requirement.

Notwithstanding some conceptual overlap, these three requirements offer an elegant way of operationalizing the Court's rather opaque language in cases like Caldor and Cutter. Yet on further examination, they also reveal significant problems with the third-party thesis. Indeed, it is difficult to avoid the conclusion that, if the third-party thesis is right, several of the Court's most celebrated religious liberty cases are almost surely wrong.

1. The religious institution cases.

To begin, consider Corporation of Presiding Bishop of Church of Jesus Christ of Latter-Day Saints v Amos. ${ }^{119}$ In Amos, the Court unanimously concluded that Title VII's exemption allowing religious organizations to hire only members of their own religion was permissible under the Establishment Clause. ${ }^{120}$ In

116 Gedicks and Koppelman, 67 Vand L Rev En Banc at 56-57 (cited in note 114). See also Gedicks and Van Tassell, 49 Harv CR-CL L Rev at 363-64 (cited in note 23); Tebbe, Religious Freedom in an Egalitarian Age at 57-58 (cited in note 23).

117 Gedicks and Van Tassell, 49 Harv CR-CL L Rev at 366 (cited in note 23).

118 Tebbe, Religious Freedom in an Egalitarian Age at 63 (cited in note 23). See also Nelson Tebbe, Micah Schwartzman, and Richard Schragger, How Much May Religious Accommodations Burden Others?, in Holly Fernandez Lynch, I. Glenn Cohen, and Elizabeth Sepper, eds, Law, Religion, and Health in the United States 215, 219-23 (Cambridge 2017).

119483 US 327 (1987).

120 Id at 339-40. 
doing so, the Court squarely rejected the claim of a plaintiff who claimed that the exemption forced him to choose between "conforming to certain religious tenets or losing a job opportunity."121

If any case implicated the third-party thesis, Amos was it. The situation in Amos met the redistribution requirement because the cost of the accommodation was borne directly by the terminated employee. It satisfied the causation requirement because the exemption clearly placed a new burden on the employee by depriving him of an otherwise available statutory protection. And the facts of Amos met the weightiness requirement because the cost to the employee as a result of the exemption was more than de minimis. Yet the Court explicitly rejected the Establishment Clause challenge. If the third-party thesis is right, Amos is almost surely wrong.

An even more difficult version of the problem arises when one considers Hosanna-Tabor Lutheran Church \& School $v$ Equal Employment Opportunity Commission.122 In HosannaTabor, a teacher at a church-affiliated school brought a discrimination lawsuit after the school dismissed her, claiming she was fired because of a medical condition. The Court unanimously rejected the teacher's claim by applying what is known as the "ministerial exception," a constitutionally mandated exemption that bars discrimination lawsuits relating to the hiring and firing of a religious organization's leaders. ${ }^{123}$ In rejecting the teacher's claim, the Court held that the ministerial exception is required under both Religion Clauses whenever a law creates "government interference with an internal church decision that affects the faith and mission of the church." 124

Like Amos, Hosanna-Tabor falls squarely within the thirdparty thesis. The redistribution requirement was satisfied because the cost of the exemption was borne by the teacher whose discrimination claim was rejected. Moreover, there was no problem satisfying either the causation requirement or the weightiness requirement. On any reading of the case, the ministerial exception deprived the teacher of the right to prove she was discriminated against, and the cost to her financial and reputational interests was significant. Yet in Hosanna-Tabor, the Court

\footnotetext{
121 Id at 340 (Brennan concurring in the judgment).

122565 US 171 (2012).

123 Id at $188-89$.

124 Id at 190.
} 
didn't ignore the Establishment Clause. It unanimously declared that the Establishment Clause commanded this result.

Proponents of the third-party thesis have tried to explain these inconsistencies away. But their explanations are unconvincing. For instance, some argue that Amos is an "exception" to the third-party thesis that was justified by the need to protect "the church's associational rights." 125 But the whole point of the Establishment Clause challenge in Amos was that the exemption went far beyond any association-based rationale-after all, the plaintiff was a janitor at the church-affiliated gym, not a religious leader.126 Likewise, others have suggested that Amos is consistent with the third-party thesis because it rests on a church autonomy right growing out of, but not mandated by, either the Free Exercise Clause or the Establishment Clause. ${ }^{127}$ But if the accommodation in Amos was not required by the Constitution, it is very difficult to see why an appeal to free exercise or nonestablishment "interests" should trump an actual Establishment Clause rule against third-party harm.

The explanations for Hosanna-Tabor are even less satisfying. Some proponents of the theory argue that the third-party thesis did not apply in that case because the result in HosannaTabor was mandated by the Constitution, and "[i]t would make little sense to find that the affirmative command of the Free Exercise Clause facially violates the negative prohibition of the Establishment Clause." 128 But the fact that the thesis leads to a clash between the Religion Clauses is not a reason to apply one clause rather than the other. On the contrary, it is strong evidence that this interpretation of the Establishment Clause is likely incorrect. Perhaps recognizing this problem, others have

125 Tebbe, Religious Freedom in an Egalitarian Age at 56-57 (cited in note 23). See also Gedicks and Van Tassell, 49 Harv CR-CL L Rev at 370-71 (cited in note 23) (arguing that Amos "gave [] religious nonprofit organizations the same right held by secular cause-based nonprofits to discriminate in favor of employees who affirm and live according to the principles on which the organization is founded").

126 See Boy Scouts of America v Dale, 530 US 640, 648 (2000) (observing that an expressive association has the right to resist forced inclusion of an unwanted person but only if "the presence of that person affects in a significant way the group's ability to advocate public or private viewpoints"). For an interesting take on the complicated relationships between religious organizations and nonadherents, especially in the context of providing social services, see generally Thomas C. Berg, Partially Acculturated Religious Activity: A Case for Accommodating Religious Nonprofits, 91 Notre Dame L Rev 1341 (2016).

127 See Gedicks and Van Tassell, 49 Harv CR-CL L Rev at 369-70 (cited in note 23).

$128 \mathrm{Id}$ at 356. See also id at $368 \mathrm{n} 118$ (noting that Hosanna-Tabor is a "mandatory accommodation"). 
suggested that Hosanna-Tabor's violation of the third-party thesis was justified by the church's overriding interest in freedom of association, much like the argument about Amos. ${ }^{129}$ But as even proponents of that view acknowledge, the Court in Hosanna-Tabor explicitly rejected the association rationale as the basis for its decision. ${ }^{130}$ What is more, the Court unanimously held that its decision was commanded by the Establishment Clause. Thus, we are left mostly where we started. If the thirdparty thesis is right, the Court's unanimous decisions in both Amos and Hosanna-Tabor must be wrong.

2. The religious conduct cases.

The third-party thesis also faces significant difficulties when compared to the Court's cases involving accommodations for religious conduct. Here, a good starting place is Wisconsin $v$ Yoder, ${ }^{131}$ one of the Court's most celebrated free exercise cases.

In Yoder, the Court held that the Free Exercise Clause required an exemption for Amish parents from laws requiring that children attend school until the age of sixteen. In ruling in favor of the religious claimants, the Court acknowledged that accommodations may at times be limited by the Establishment Clause. ${ }^{132}$ Yet the Court was adamant that "[such] danger cannot be allowed to prevent any exception no matter how vital it may be to . . . the right of free exercise." 133

Supporters of the third-party thesis contend that their rule did not apply in Yoder because the causation requirement was not satisfied: the Court found that it was "highly speculative" that the exemption would leave children "ill-equipped for life."134 But focusing on that language diverts attention from the more obvious cost-shifting that Yoder presented. As the Court observed, the mandatory school attendance regime was clearly designed to protect children and their "substantive right ... to a

129 Tebbe, Religious Freedom in an Egalitarian Age at 57 (cited in note 23).

130 See Hosanna-Tabor, 565 US at 189 (2012) (stating that the association rationale is "hard to square with the text of the First Amendment itself, which gives special solicitude to the rights of religious organizations"). See also Tebbe, Religious Freedom in an Egalitarian Age at 86 n 10 (cited in note 23).

131406 US 205 (1972).

132 See id at $220-21$.

133 Id at 221.

134 Id at 224. See also Nelson Tebbe, Richard Schragger, and Micah Schwartzman, Reply to McConnell on Hobby Lobby and the Establishment Clause (Balkinization, Mar 30, 2014), archived at http://perma.cc/K4CE-T9GX. 
secondary education." ${ }^{135}$ Yet the Court did not view deprivation of this right as a reason to deny the exemption. On the contrary, the Court silently accepted that its ruling might well deny schooling to an unwilling child, but nonetheless concluded that the exemption was appropriate because it did not present "any harm to the physical or mental health of the child or to the public safety" sufficient to constitute a compelling interest. ${ }^{136}$ Once again, if the third-party thesis is right, Yoder seems to be wrong.

There is also a deeper sense in which the Court's religious conduct cases present significant difficulties for the third-party thesis. Recall that, under the redistribution requirement, there is a firm distinction between accommodations that shift costs to discrete private parties and those that merely impose a cost on the government or the public at large. But as we have already seen, the primary Establishment Clause theory supporting the thesis involves an analogy to church taxes: accommodations that shift costs to others violate the Establishment Clause because they function like taxes requiring one person to pay for another person's religion. ${ }^{137}$ Yet if the problem with cost-shifting accommodations is that they function like religious taxes, it is difficult to see why accommodations using actual tax dollars are acceptable but those that incidentally generate costs for some smaller group are not. ${ }^{138}$

135 Yoder, 406 US at 229

136 Id at 230. In holding as much, the Court noted that only one of the three children involved in the case provided any testimony as to whether she shared her parents' convictions. See id at 231 n 21; id at 237 (Stewart concurring).

137 See Part II.A.

138 Supporters of the third-party thesis argue in favor of the distinction by insisting that the Establishment Clause is not implicated when the costs of an accommodation are "widely distributed among a large and indeterminate class." Gedicks and Koppelman, 67 Vand L Rev En Banc at 56 (cited in note 114). See also Schwartzman, Tebbe, and Schragger, $106 \mathrm{Ky} \mathrm{L} \mathrm{J} \mathrm{at} 786$ (cited in note 83) (arguing that there is a firm distinction between "[g]overnment tax[ing] the public to provide kosher meals to Jewish inmates" and "[g]overnment tax[ing] nonreligious inmates to provide kosher meals to Jewish inmates"). But given their underlying theory, it is difficult to see why that matters. After all, Madison famously suggested that being forced to pay even "three pence" was just as objectionable as any other form of establishment. Madison, Memorial and Remonstrance at 57 (cited in note 79). As already noted, Madison's argument is best understood as insisting that forced religious observances (even trivial ones) are odious to religious freedom. See notes 80-81 and accompanying text. But proponents of the third-party thesis read arguments like Madison's as condemning all forms of unwilling support for religion. And if that is so, there seems little reason to think the objection dissipates because the cost to any particular citizen is minimal.

What is more, there is good reason to think that the distinction between accommodations involving general taxes and those involving targeted costs is itself largely illusory. 
Of course, the most obvious way to address this difficulty would be to widen the third-party thesis to prohibit any accommodation that generates costs, no matter who bears them. The moment we do so, however, an even larger number of the Court's religious conduct precedents become inexplicable. The Court has repeatedly upheld religious accommodations that involve state benefits despite the fact that they cost taxpayers money. ${ }^{139}$ It has endorsed accommodations that use tax dollars to provide kosher meals for inmates and provide chaplains for members of the military. ${ }^{140}$ And most recently, it has said that the government can pay for medical benefits like contraception when religious employers are exempted from doing so. ${ }^{141}$ Yet the third-party thesis would seem to imply that all those cases were also wrongly decided, or at least rest on dubious grounds.

A similar problem plagues the causation requirement. Remember that, under this requirement, a religious accommodation does not violate the Establishment Clause unless it imposes a new burden (as opposed to a nontraceable increase in some existing burden). Proponents of the thesis have used this

For example, accommodation claims involving unemployment compensation require the government to pay for benefits when a claimant's religious practice conflicts with a requirement that she be available to work on Saturdays. Yet those accommodations also inevitably involve a private cost: "Unemployment compensation is generally experiencerated, so an employer's unemployment tax payments are tied to the number claims the employer has to pay out." Eugene Volokh, A Common-Law Model for Religious Exemptions, 46 UCLA L Rev 1465, 1513-14 \& n 154 (1998). For an insightful discussion of this same point in the prison context and the many other instances in which the distinction between accommodations involving general taxes and those involving targeted costs breaks down, see Stephanie H. Barclay, First Amendment Categories of Harm, 95 Ind L J *26-33 (forthcoming 2020), archived at http://perma.cc/X2DX-BPDG.

139 See, for example, Sherbert $v$ Verner, 374 US 398, 407-09 (1963) (holding that the government could not deny unemployment compensation to a claimant for refusing to work on Saturday because of her religious beliefs); Thomas $v$ Review Board of the Indiana Employment Security Division, 450 US 707, 720 (1981) (holding that the government's denial of unemployment compensation violated a claimant's free exercise rights when his religious beliefs forbade him from producing weapons); Hobbie $v$ Unemployment Appeals Commission of Florida, 480 US 136, 146 (1987) (holding that a state's denial of unemployment compensation to a claimant who refused to work on the Sabbath violated her free exercise rights); Frazee $v$ Illinois Department of Employment Security, 489 US 829, 835 (1989) (same).

140 See Cutter, 544 US at $721 \&$ n 10 (2005) (acknowledging that RLUIPA would likely require religiously compliant meals and indicating that such accommodations are appropriate). See also id at 722 (noting and praising the Army chaplaincy program). For an insightful discussion on this point, see Christopher C. Lund, Religious Exemptions, Third-Party Harms, and the False Analogy to Church Taxes, 106 Ky L J 679, 681-82 (2017-2018)

141 Hobby Lobby, $134 \mathrm{~S}$ Ct at 2781-82. 
requirement to explain why draft exemptions from military service fit their rule: because individuals can't draw a clear causal link between exempting a particular conscientious objector and being drafted themselves, the third-party thesis doesn't apply. But this explanation is also illusory. As Professor William Marshall has shown, in modern draft lotteries like those used during the Vietnam War, we actually can draw a line between particular draftees and particular objectors. ${ }^{142}$ And in response, supporters of the thesis have quietly hinted that, under their rule, conscientious exemptions from military service (religious as well as secular) very likely violate the Establishment Clause as well. ${ }^{143}$ So the Court's famous Draft Cases ${ }^{144}$ also appear to be wrongly decided. But more than this: the venerable practice of granting exemptions from military service that existed at the Founding and has continued throughout the country's history has likely been unconstitutional all along.

There is a pattern here. Supporters of the third-party thesis claim the theory is consistent with the Court's precedents. But on closer inspection, that claim-like the theoretical justification-falls short. To be sure, there is a sense in which the costs of accommodations are relevant to assessing their constitutionality, as I explain in more detail below. ${ }^{145}$ To make sense of the problem, however, we need to start in a different place.

\section{LIMITING RELIGIOUS ACCOMMODATION}

Neither constitutional principle nor the Supreme Court's precedent supports the idea that religious accommodations violate the Establishment Clause because they generate costs. This is not to say, however, that the Establishment Clause has nothing to say about accommodations that impact others. On the

142 As Marshall explains, the lottery system involved assigning numbers seriatim to potential draftees, who were then drafted in numerical order until the government's manpower needs were satisfied. Thus, exempting religious objectors with low numbers from combat service necessarily meant that some individuals with higher numbers would not have been called but for the exemptions. For more explanation on this point, see William P. Marshall, Third-Party Burdens and Conscientious Objection to War, 106 Ky L J 685, 706 (2017-2018).

143 See, for example, Schwartzman, Tebbe, and Schragger, 106 Ky L J at 805 (cited in note 83) ("[T] the extent conscientious objectors to military service impose harms on identifiable third parties, others can rightfully complain about the fairness of having to carry those burdens.").

144 See United States v Seeger, 380 US 163, 165-66 (1965); Welsh v United States, 398 US 333, 343-44 (1970) (Black) (plurality).

145 See Part IV.A. 
contrary, the Establishment Clause is deeply concerned with certain kinds of costs associated with accommodation-most fundamentally, those that play a role in fostering religious conformity. This Part explains that limitation first by discussing some general Establishment Clause doctrine, then by exploring several important incidents from Founding-era history involving the connection between accommodations and religious establishments. Having done so, it turns finally to a more detailed discussion of the Court's precedents.

\section{A. Against Religious Conformity}

The word "establishment" implies social control. When people speak about the "literary establishment," the "political establishment," or even just "the establishment," they mean not just that a group holds power but also that its power has a role in shaping the behavior of others. And whether the relevant orthodoxy involves social niceties, artistic conventions, or political opinions, all establishments do the same thing. They pressure people to conform.

This concern over social control-and especially government-induced conformity-was prominent in Foundingera descriptions of religious establishment. For instance, Baptist minister John Leland, one of the most important supporters of the Religion Clauses in James Madison's home state of Virginia, observed that the aim of religious establishment is to "establish some standard of orthodoxy, to effect uniformity."146 As Leland described it: "Uninspired, fallible men make their own opinions tests of orthodoxy, and use their own systems, as Pocrustes used his iron bedstead, to stretch and measure the consciences of all others by." 147

Others echoed the same point. In his famous statute for religious freedom, Thomas Jefferson complained that establishments stem from "the impious presumption of legislators," who "set[] up their own opinions and modes of thinking as the only true and infallible, and as such endeavoring to impose them on others." 148 Moreover, Jefferson made clear that his concern involved not just punishments but also government's efforts to

146 John Leland, The Rights of Conscience Inalienable, reprinted in L.F. Greene, ed, The Writings of the Late Elder John Leland 177, 184 (G.W. Wood 1845).

147 Id at 182.

148 Thomas Jefferson, A Bill for Establishing Religious Freedom, June 18, 1779, reprinted in Julian P. Boyd, ed, 2 The Papers of Thomas Jefferson 545 (Princeton 1950). 
promote a favored religion by "bribing, with a monopoly of worldly honours and emoluments, those who will externally profess and conform to it." 149

The emphasis on social control was also a central theme unifying the historical practices associated with religious establishments. As several scholars have observed, these practicesbegun in England and often carried over to the American context-included governmental control over religious doctrine, mandatory attendance at worship services, limitations on the religious activities of dissenters, public financial support for favored churches, and religious limitations on eligibility for office and participation in public life. ${ }^{150}$ The shape of these practices and their administration differed from colony to colony and also changed over time as Americans wrestled over the meaning of "establishment" and expanded rights for religious dissenters. ${ }^{151}$ But despite differences in application, it seems clear that these practices all aimed at "government control over religion" and, more specifically, "the promotion and inculcation of a common set of beliefs through government authority." 152 When rulers wanted to control their subjects, controlling the religious beliefs of the populace was-and continues to be-a powerful tool.

The same worry about government-induced conformity was also a primary motivating force behind the adoption of the Establishment Clause specifically. Many Anti-Federalists worried that, given the scope of the national government's powers, Congress might, "if they shall think it for the 'general welfare,' establish an uniformity in religion throughout the United States." ${ }^{153}$ Thus, when explaining the draft that eventually

149 Id at 546.

150 See, for example, Michael W. McConnell, Establishment and Disestablishment at the Founding, Part I: Establishment of Religion, 44 Wm \& Mary L Rev 2105, 2131-81 (2003) (documenting these practices); Douglas Laycock, Regulatory Exemptions of Religious Behavior and the Original Understanding of the Establishment Clause, 81 Notre Dame L Rev 1793, 1798-1803 (2006) (same).

151 For one important account of these changes, see generally Thomas J. Curry, The First Freedoms: Church and State in America to the Passage of the First Amendment (Oxford 1986). See also Noah Feldman, The Intellectual Origins of the Establishment Clause, 77 NYU L Rev 346, 398-405 (2002) (exploring differences in colonial practice but emphasizing a common concern with liberty of conscience).

152 McConnell, 44 Wm \& Mary L Rev at 2207, 2131 (cited in note 150).

153 Essay by Deliberator, Philadelphia Freeman's Journal (Feb 20, 1788), reprinted in Herbert J. Storing, ed, 3 The Complete Anti-Federalist 176, 179 (Chicago 1981). For a discussion of Anti-Federalist arguments along this line and their relation to other arguments against the Constitution, see Vincent Phillip Muñoz, The Original Meaning of the 
became the Religion Clauses, Madison stated that he believed the addition to the Constitution was necessary because "people feared one sect might obtain a pre-eminence, or two combine together, and establish a religion to which they would compel others to conform." 154 From the first, the Establishment Clause was understood as a limit on government's ability to control the religious lives of its citizens. ${ }^{155}$

But concern over government-induced religious conformity is not just a historical artifact. It has also been a prominent theme in the Court's modern Establishment Clause jurisprudence. In the School Prayer Cases, for instance, the Court famously concluded that the Establishment Clause forbids government-initiated religious exercises in public schools. ${ }^{156}$ In so holding, the Court announced that the Establishment Clause prohibits government from exerting "indirect coercive pressure upon religious minorities to conform to the prevailing officially approved religion." 157 As Justice Brennan explained it, "[T]he Establishment Clause permits little doubt that its prohibition was designed comprehensively to prevent those official involvements of religion which would tend to foster ... religious worship or belief." 158

A similar theme condemning attempts to foster religious conformity runs through the Court's cases regarding funding for religious institutions. In Zelman v Simmons-Harris, ${ }^{159}$ the Court made plain that government may choose to fund religious

Establishment Clause and the Impossibility of Its Incorporation $8 \mathrm{U}$ Pa J Const L 585, 614-19 (2006).

1541 Annals of Congress 758 (Aug 15, 1789). Two printings exist of the first two volumes of the Annals of Congress. The first printing with the running head "History of Congress" conforms to the remaining volumes of the series, while the second printing with the running head "Gales \& Seaton's history of debates in Congress" is unique. See Checklist of United States Public Documents 1789-1909 1463 (Government Printing Office 3d ed 1911). All page citations herein are to the latter printing. Readers with the "History of Congress" printing can find parallel citations by referring to the date.

155 In this sense, the focus of the Establishment Clause has always been about limiting government power, not securing individual rights. See Carl H. Esbeck, The Establishment Clause as a Structural Restraint on Government Power, 84 Iowa L Rev 1, 3 (1998) (explaining that the Establishment Clause, like other structural provisions in the Constitution, protects rights by "constraining the ... government to act only within the scope of [its] delegated powers").

156 See School District of Abington Township v Schempp, 374 US 203, 223 (1963);

Engel $v$ Vitale, 370 US 421, 424 (1962).

157 Engel, 370 US at 431.

158 Schempp, 374 US at 234 (Brennan concurring).

159536 US 639 (2002). 
schools alongside others without violating the Establishment Clause. ${ }^{160}$ Central to that holding, however, was the Court's caveat that such programs must not "deliberately skew[] incentives" in favor of religious schools. 161 While programs of "true private choice" are acceptable under the Establishment Clause, programs that are gerrymandered to encourage the state's preferred religious activity are not. 162

Likewise, although the Court's cases involving displays of religious symbols are often confused, they also can be read to follow the same pattern. Indeed, the recurring element in all these cases seems to be whether the "context of the display" indicates a "governmental effort substantially to promote religion." 163 To be sure, the justices do not agree as to what the relevant baseline should be. But whether it involves past historical practice, ${ }^{164}$ "ceremonial deism," 165 or a general version of the endorsement test, ${ }^{166}$ the limit seems to be the same: government may sometimes speak in ways that include religion, but it may not "proselytize on behalf of a particular religion." 167

Given all of this, it should be no surprise that the Court has said that there is "ample room" for religious accommodation under the Establishment Clause. ${ }^{168}$ The reason is simple: accommodations almost always weaken, rather than strengthen, the power of the state to foster religious uniformity. Indeed, it is no exaggeration to say that, as a practice, accommodation stands in direct opposition to religious establishment. Whereas establishments exist to encourage the state's preferred religion, accommodations preserve free exercise by minimizing the government's power over religious activity.

\footnotetext{
160 Id at 653.

161 Id at 650 .

162 Id at 649 .

163 Van Orden v Perry, 545 US 677, 701, 703 (2005) (Breyer concurring in the judgment).

164 See McCreary County v American Civil Liberties Union of Kentucky, 545 US 844, 894 (2005) (Scalia dissenting) (arguing that "[h]istorical practices" demonstrate that "there is a distance between the acknowledgment of a single Creator and the establishment of a religion").

165 Elk Grove Unified School District v Newdow, 542 US 1, 36-37 (2004) (O'Connor concurring in the judgment) (suggesting that this concept distinguishes permissible religious symbols from impermissible ones).

166 See, for example, Lynch v Donnelly, 465 US 668, 687-94 (1984) (O'Connor concurring) (explaining this approach).

167 County of Allegheny $v$ American Civil Liberties Union Greater Pittsburgh Chapter, 492 US 573, 661 (1989) (Kennedy concurring in part and dissenting in part).

168 Amos, 483 US at 334.
} 
That theme is also consistent with history. The earliest religious accommodations provided exemptions from statesponsored worship. ${ }^{169}$ Those exemptions left dissenters free to practice their religion. But they also limited the ability of government to manage dissemination of religious ideas. Likewise, accommodations from oath requirements during the Founding period ensured that citizens with religious objections could still testify in court or hold public office. ${ }^{170}$ But more basically, they prevented government from cooperating with an established church to exclude religious minorities from political life. Even exemptions from militia service shored up the idea that, as Congress put it, government had the right to demand from its citizens only forms of service "consistent[] with their religious principles."171 From the beginning, religious accommodation-like disestablishment-weakened the state's power to promote a favored orthodoxy or link religious membership to political power.

But what about instances in which the relationship between accommodation and government-induced religious conformity was more complicated? Generally, commentators besides those advocating for the third-party thesis have focused on the fact that accommodations were "never part of the establishment."172 But that emphasis has neglected an important subsidiary point: members of the Founding generation did equate accommodations with establishments on at least two occasions, both of which involved situations in which an accommodation risked promoting rather than discouraging religious conformity. My contention is that, although these historical incidents fall short of providing conclusive proof of the original meaning of the Establishment Clause, they nonetheless offer significant insight into how religious accommodations should be limited under the clause today.

169 See Laycock, 81 Notre Dame L Rev at 1803-04 (cited in note 150) (discussing these exemptions).

170 See McConnell, 103 Harv L Rev at 1467-68 (cited in note 1) (discussing these exemptions); Laycock, 81 Notre Dame L Rev at 1804-05 (cited in note 150) (same).

171 Resolution of July 18, 1775, in Worthington Chauncey Ford, ed, 2 Journals of the Continental Congress, 1774-1789 187, 189 (GPO 1905).

172 See, for example, Laycock, 81 Notre Dame L Rev at 1803 (cited in note 150). See also McConnell, 103 Harv L Rev at 1511 (cited in note 1) (suggesting that "[t]here is no substantial evidence that [ ] exemptions were considered constitutionally questionable [] as a form of establishment"). 
1. Virginia's General Assessment.

The first incident occurred during the debate over Virginia's General Assessment. As observed in the discussion of the thirdparty thesis, the assessment was a targeted tax that would have required all citizens of Virginia to support "a Minister or Teacher of the Gospel ... [or] places of divine worship." 173 Yet the bill also contained two provisions specifically designed to placate objections from dissenters. First, it provided citizens the right to direct their taxes to a church of their choice or, if no such designation was made, to "seminaries of learning within the Counties."174 Second, it provided a specific exemption for Quakers and Mennonites that allowed them to use the funds collected for any purpose, rather than limiting their use to payment of a minister or the maintenance of church buildings. ${ }^{175}$

The assessment drew support from many in Virginia, including George Washington, who favored its goal of "preserv[ing] the peace of society" through "the general diffusion of Christian knowledge."176 But Madison and Jefferson took a different view. Madison made an impassioned speech to the Virginia legislature at the close of the 1784 session opposing the assessment. ${ }^{177} \mathrm{He}$ also repeated many of those arguments the next year in his nowfamous Memorial and Remonstrance. ${ }^{178}$

Madison began his Memorial and Remonstrance by rejecting the conclusion of Washington and others that the assessment did not impinge on religious liberty. He first observed that because "[i]t is the duty of every man to render to the Creator such homage and such only as he believes to be acceptable to

173 A Bill Establishing a Provision for Teachers of the Christian Religion at 189 (cited in note 78 ).

174 Id.

175 Id.

176 Id at 188. When George Mason wrote to Washington to request that he sign a remonstrance opposing the assessment, Washington replied:

Although no man's sentiments are more opposed to any kind of restraint upon religious principles than mine are, yet I must confess, that I am not amongst the number of those, who are so much alarmed at the thoughts of making people pay towards the support of that which they profess, if of the denomination of Christians, or declare themselves Jews, Mahometans, or otherwise, and thereby obtain proper relief.

Letter from George Washington to George Mason (Oct 3, 1785), in Worthington Chauncey Ford, ed, 10 The Writings of George Washington 1782-1785 506 (G.P. Putnam's Sons 1891).

177 For the notes of Madison's speech, see James Madison, Notes on Debate (Dec 1784), in Alley, ed, James Madison on Religious Liberty at 54-55 (cited in note 79).

178 Madison, Memorial and Remonstrance at 55 (cited in note 79). 
him," it is "the right of every man" to exercise religion only as conscience dictates. ${ }^{179}$ Madison subsequently argued that the assessment "abridged" that right because it required each citizen to tithe whether such an action was warranted by conscience or not.180 "Who does not see," Madison reasoned, "that the same authority which can force a citizen to contribute three pence ... may force him to conform to any other establishment in all cases whatsoever?"181

Yet Madison also went much further. Specifically, he contended that, besides being a forced religious observance, the assessment also "violate[d] that equality which ought to be the basis of every law." 182 For our purposes, the most important part of that argument was Madison's claim that the assessment granted "peculiar exemptions." Madison continued:

Are the Quakers and Menonists the only sects who think a compulsive support of their Religions unnecessary and unwarrantable? Can their piety alone be entrusted with the care of public worship? Ought their Religions to be endowed above all others with extraordinary privileges by which proselytes may be enticed from all others? ${ }^{183}$

Madison ended the argument by pleading with Quakers and Mennonites not to be seduced by the offer of "pre-eminences over their fellow citizens." 184

There is little doubt that, by using the language of "preeminences" and "extraordinary privileges," Madison intended to draw an analogy between the accommodation for Quakers and Mennonites and traditional religious establishments. ${ }^{185}$ Nonetheless, commentators have generally dismissed this section of the Memorial and Remonstrance as unprincipled political posturing. The reason, so it is said, is that Madison's argument was disingenuous: Quakers and Mennonites had no formal clergy and thus would have had little use for money to

179 Id at 56.

$180 \mathrm{Id}$.

181 Id at 57.

182 Madison, Memorial and Remonstrance at 57 (cited in note 79).

$183 \mathrm{Id}$.

$184 \mathrm{Id}$.

185 In so arguing, Madison was explicitly rejecting the assessment's assertion that it provided support for religion "without counteracting the liberal principle heretofore adopted and intended to be preserved by abolishing all distinctions of preeminence amongst the different societies or communities of Christians." A Bill Establishing a Provision for Teachers of the Christian Religion at 188 (cited in note 78). 
pay a minister. ${ }^{186}$ But that dismissal overlooks the crucial way in which Madison thought that accommodations offering "privileges by which proselytes may be enticed" could be analogized to establishments. ${ }^{187}$

The important point concerns the contours of the exemption and its connection to proselytizing. Contrary to arguments by many commentators, the assessment didn't just excuse Quakers and Mennonites from using tax revenues to pay a minister. It excused them from all limitations imposed on the funds and instead allowed them to use the money "in a[ny] manner . . . calculated to promote their particular mode of worship."188 That permission had an important consequence. Whereas other religious groups were constrained to use the tax to pay for only internal church functions-clergy salaries or worship spaces-Quakers and Mennonites were free to use the money to actively recruit converts by financing missionary activities, pamphlets, or other forms of proselytizing. ${ }^{189}$ In short, the exemption resembled an establishment because it ensured that only those religious groups possessed the "extraordinary privilege[]" of using government money to propagate their message to those outside the faith. 190

186 See, for example, Steven D. Smith, Blooming Confusion: Madison's Mixed Legacy, 75 Ind L J 61, 65-66 (2000) (making this argument); Buckley, Church and State in Revolutionary Virginia, 1776-1787 at 133-34 (cited in note 78) (same); Gene R. Nichol, Establishing Inequality, 107 Mich L Rev 913, 922 (2009) (same). See also McConnell, 103 Harv L Rev at 1454 (cited in note 1) (labeling the passage "ambiguous").

187 Madison, Memorial and Remonstrance at 57 (cited in note 79).

188 A Bill Establishing a Provision for Teachers of the Christian Religion at 189 (cited in note 78).

189 Madison, Memorial and Remonstrance at 57 (cited in note 79). See also Edward L. Bond, ed, Spreading the Gospel in Colonial Virginia: Sermons and Devotional Writings 27 (Lexington 2004) (noting that Quakers in eighteenth century Virginia were "energetic proselytizers, and they sought to draw converts ... by distributing Quaker religious tracts to the colony's many unchurched and underchurched settlers").

190 The idea that members of the Virginia legislature would want to support Quakers and Mennonites over all other dissenting sects may seem curious. But a possible explanation is deducible from the religious situation in Virginia at the time the assessment was being debated. It was no secret that, like Quakers, Baptists in Virginia vehemently objected to church taxes for ministers. Yet Baptists were also hated by the Virginia gentry. Whereas by the 1780 s Quakers had been accepted as a peaceful and industrious people, Baptists were described as "swarms" of gnats and radicals who "cannot meet a man upon the road ... [without] ram[ming] a text of Scripture down his throat." See id at 26, 35-36. Nonetheless, Baptists were easily the fastest growing religious group in Virginia. Id at 36. Allowing Quakers and Mennonites to proselytize using government dollars was unlikely to threaten the de facto Anglican establishment in Virginia. But supporters may have thought it could slow the "torrent" of Baptist converts. Id at 36 . 
To be sure, one might question whether this reading of Madison's Memorial and Remonstrance is just wishful thinking. After all, Madison failed to explain his argument about the exemption for Quakers in any detail, which might suggest the rhetorical interpretation is the right one. But other evidence suggests that the problem is actually historical distance: Madison's argument sounded much more familiar to his contemporaries than it does to us, making the need for elaboration unnecessary. Throughout the colonies but especially in Virginia, authorities had long limited the spread of disfavored religious ideas by requiring licenses to preach, then granting those licenses only to favored religious groups or using them to limit religious activity. ${ }^{191}$ And indeed, at least one notable contemporary in Virginia specifically referred to those licenses as "claimable Priviledges," which were often denied to dissenters on the basis of false pretenses or bare hostility. ${ }^{192}$ Read against that background, it seems plausible if not likely that Madison's readers would have understood his argument in a similar way. An exemption from the general assessment for Quakers and Mennonites might look like a reasonable accommodation. But in fact, it acted just like the licensing regimes of traditional establishments: it leveraged government power to grant special advantages to some kinds of religious messages over others, and by doing so, it increased government's power over religious life more generally.

Madison ultimately won the debate over Virginia's General Assessment, though it is impossible to say what role his argument about the exemption played in the victory. Yet its connection to the controversy over preaching licenses suggests that, at the very least, Madison's argument drew on more general

191 See McConnell, 44 Wm \& Mary L Rev at 2163-66 (cited in note 150) (explaining this practice in Virginia and its impact on religious dissenters); id at 2119 (observing that as late as 1774, Baptist ministers in Virginia "were still being horsewhipped and jailed . . . for preaching without a license").

192 Letter from Samuel Davies to Joseph Bellamy, The State of Religion among the Protestant Dissenters in Virginia (June 28, 1751), online at http://quod.lib.umich.edu/cgi/t/text/text-idx?c=evans;cc=evans;rgn=div1;view=text;idno= N05267.0001.001;node=N05267.0001.001:2 (visited Mar 16, 2019) (Perma archive unavailable) (recounting an instance in which a fellow minister's request for certification was rejected "under Pretence" and contrasting this with the behavior of other officials who "always discovered a ready Disposition to allow us all claimable Priviledges"). See also Curry, First Freedoms at 99-100 (cited in note 151) (explaining Samuel Davies's important role in challenging the licensing regime for ministers in Virginia). 
arguments against religious establishments that were common by the time the Establishment Clause was adopted. Regardless of its precise impact, however, Madison's argument offers a principle that can be extended beyond its specific historical context: although accommodations generally have little connection to establishment, when an accommodation selectively subsidizes the government's preferred religious messages, it ought to be considered a pretext for fostering government-induced religious conformity.

Nonetheless, more still needs to be said. For although Madison's argument offers an important insight, a second historical incident-this one following congressional debate over the Establishment Clause-offers a second significant example of how accommodations might be equated with religious establishments.

\section{The Uniform Militia Act.}

Leading up to the ratification of the Bill of Rights, Congress considered a religious exemption as part of what we now know as the Second Amendment. It guaranteed that "no person religiously scrupulous shall be compelled to bear arms" and was essentially identical to proposed language Madison had included in his draft bill of rights. ${ }^{193}$ The provision incited vigorous debate but ultimately failed to garner the necessary support.194 Commentators have rightly concluded that " $t]$ here is no hint in this debate of any issue concerning establishment." 195 Yet they have quite remarkably ignored the fact that the issue resurfaced again a little over a year later during debates over the Uniform Militia Act.

In its original form, the Uniform Militia Act created a general requirement of militia service among eligible males, but it

1931 Annals of Congress 778 (Aug 17, 1789). See also id at 451 (June 8, 1789) (“[N]o person religiously scrupulous of bearing arms shall be compelled to render military service in person.”).

194 Different members opposed the amendment for different reasons, but the predominant reason seems to have been the belief that such an exemption should be left to legislative discretion. For instance, Egbert Benson of New York argued that "the Legislature will always possess humanity enough to indulge this class of citizens in a matter they are so desirous of; but they ought to be left to their discretion." Id at 780 (Aug 17, 1789). Likewise, Thomas Scott of Pennsylvania suggested that the right to a militia exemption was "a legislative right altogether." Id at 796 (Aug 20, 1789). See also McConnell, 103 Harv L Rev at 1500-03 (cited in note 1) (summarizing the debate).

195 Laycock, 81 Notre Dame L Rev at 1810 (cited in note 150). 
provided an exemption for certain classes of citizens if they paid two dollars to the United States in lieu of service. Such monetary penalties were particularly worrisome to Quakers, who appeared in person before Congress and asserted that such payments "manifestly infringe[d] on the rights of conscience."196 Some members of Congress agreed. For instance, Representative Aedanus Burke of South Carolina insisted that it was "not [] consonant with the principles of justice to make those conscientiously scrupulous of bearing arms to pay for not acting against the voice of their conscience."197

Others were not convinced. Most notably, Representative James Jackson, a hardened veteran of the Revolutionary War and one of the most prominent opponents of the original constitutional exemption, contended that if exemptions without payment were given, "very few would be found, if their own word was to be taken, not conscientiously scrupulous." 198 And when the bill came before the full House for debate, Jackson continued by offering the following argument:

[T] he operation of this privilege would be to make the whole community turn Quakers; and in this way it would establish the religion of that denomination more effectually than any positive law could any persuasion whatever. ${ }^{199}$

Unlike earlier arguments opposing a constitutional exemption, which relied on claims about fairness or the role of the legislature, Jackson's argument here explicitly raised a concern about religious establishment. Moreover, given that the argument occurred after the Establishment Clause had been debated in Congress, it seems exceedingly likely that Jackson specifically intended to invoke it. According to Jackson, even if the purpose of the accommodation was to relieve Quakers of the burden involved in either personal service or paying for a substitute, its "operation" would nonetheless create incentives toward religious conformity so overwhelming they ought to be considered an Establishment Clause violation.

Jackson's argument was met with skepticism. Madison asserted that "[h]e did not believe that the citizens of the United

196 Nicholas Waln, An Address and Memorial (1790), reprinted in David M. Gross, ed, American Quaker War Tax Resistance 221, 222 (Gross 2011).

1972 Annals of Congress 1865 (Dec 21, 1790).

198 Id.

199 Id at 1869 (Dec 22, 1790). 
States would hypocritically renounce their principles, their conscience, and their God, for the sake of enjoying the exemption." $200 \mathrm{He}$ also moved to insert a religious exemption for those refusing to bear arms and indicated he also supported exempting Quakers from payments. ${ }^{201}$ Jackson responded that Madison "had not argued with his usual ingenuity and knowledge of the human heart." ${ }^{202}$ According to Jackson, "The influence of conscience [was] a weak defence against the powerful temptations of pecuniary advantages," and exempting Quakers from both militia service and monetary payment would render Quaker converts "ten times as numerous" as they otherwise would be. ${ }^{203}$

Proponents of the exemption did not reject Jackson's premise that the incentives of an unqualified exemption might sound in religious establishment. Instead, they sought to answer Jackson by blunting the inducements toward religious conformity. For instance, one of the most outspoken supporters of the exemption, Representative Roger Sherman of Connecticut, agreed with Madison that many Quakers would never submit to a fine. Yet in an apparent attempt to address Jackson's concerns, Sherman cleverly suggested that perhaps Congress could "excus[e] part of the militia from a poll tax, so as to equalize the exemption."204 Moreover, the following day, Madison himself offered a revised proposal that provided an exemption for religious objectors who declared their sincerity before the civil magistrate, with the caveat that such objectors would "be liable to a penalty of ___ dollars, to be appropriated as the moneys arising from the post-office are appropriated." 205 By requiring a declaration as well as a monetary penalty, it seems clear that Madison's proposal aimed to address Jackson's concern that citizens might feign Quakerism to benefit from an unqualified militia exemption. At the same time, by declaring that the money from the penalty "be appropriated as the moneys arising from the postoffice are appropriated," Madison sought to alleviate Quaker concerns at least in part by ensuring that no money paid by objectors would be used to fund the militia. ${ }^{206}$

200 Id at 1872.

2012 Annals of Congress 1871 (Dec 22, 1790).

202 Id at 1872.

203 Id.

204 Id.

2052 Annals of Congress at 1874 (Dec 23, 1790).

206 Revenues generated from the post office were used to maintain the postal service and pay the relevant officials. See An Act for the Temporary Establishment of the 
Ultimately, Congress elected to leave the matter of religious exemptions from militia service to the discretion of the states. ${ }^{207}$ Nonetheless, the debate over the Uniform Militia Act is highly suggestive-it indicates that the Establishment Clause may well be implicated by accommodations that encourage religious conformity by offering incentives to adopt the accommodated religion. What is more, it also offers several clues as to how such a rule might function in practice.

Consider first the question of the baseline against which incentives should be measured. In making the argument that an exemption without requiring payment could be analogized to a religious establishment, Jackson argued that the law would have the effect of inducing others to convert to Quakerism "more effectually than any positive law could any persuasion whatever." 208 As such, the argument was not simply that the exemption provided a modest benefit to religious dissenters. Instead, Jackson's argument turned on the fact that the combination of avoiding military service and avoiding payment created an incentive so powerful that it was indistinguishable from "positive law[s]" associated with establishments-laws that, in Justice Antonin Scalia's words, were characterized by "coercion under threat of penalty." ${ }^{209}$ Generalizing the point, we might conclude that the Establishment Clause should not be understood as viewing every benefit accompanying an accommodation as raising constitutional concerns. Instead, the Establishment Clause is concerned only with accommodations whose likely effects on nonbeneficiaries are so pronounced that they are equivalent to coercive laws in their power to generate religious conformity.

Second, the debate surrounding the Uniform Militia Act suggests that, when the concern over an accommodation involves incentivizing religious conformity, the appropriate remedy is often to dissipate the incentive. Although Jackson

Post-Office, 1 Stat 70 (1789) (directing that regulations governing the post office be the same as they were under the Continental Congress); US Art of Confederation Art IX (declaring that postage on papers passing through the post offices be calibrated to "defray the expences of the said office").

207 Id at 1875 (Dec 24, 1790). And indeed, a similar debate over militia exemptions for religious objectors had already been taking place in the states and continued contemporaneous with the debate in Congress. See Laycock, 81 Notre Dame L Rev at 1810-25 (cited in note 150) (documenting the debate in Pennsylvania).

2082 Annals of Congress 1869 (Dec 22, 1790).

209 Lee v Weisman, 505 US 577, 643 (1992) (Scalia dissenting). 
believed that the incentives created by an unqualified militia exemption could be equated with religious establishment, he did not believe that this problem rendered any exemption unconstitutional. Instead, he argued that those who are exempted "ought to pay a full equivalent"-a solution that Jackson argued accorded with "every principle of justice and equity" and blunted the problem of incentives. ${ }^{210}$

Commentators have overlooked the debate over the Uniform Militia Act when considering the relationship between religious accommodations and the Establishment Clause. But taken seriously, it adds a second principle to the one identified in Madison's Memorial and Remonstrance: when an accommodation provides an exceedingly powerful incentive to adopt the religion being accommodated, it can rightly be analogized to a religious establishment.

\section{B. Modern Doctrine}

The arguments surrounding Virginia's General Assessment and the Uniform Militia Act by themselves do not offer conclusive proof of the Establishment Clause's original public meaning. But they are some of the most important instances-to my knowledge, the only instances-in which members of the Founding generation directly equated accommodations with religious establishments. Thus, if one is inclined to seek evidence of original meaning on the question of accommodation and establishment, these incidents are some of the most important evidence we possess. ${ }^{211}$ But that is not all.

2102 Annals of Congress 1870 (Dec 22, 1790).

211 To be sure, some originalists will question my use of these historical sources on the ground that any limits imposed by the Establishment Clause originally applied only to the federal government, not state legislatures. See, for example, Steven D. Smith, The Jurisdictional Establishment Clause: A Reappraisal, 81 Notre Dame L Rev 1843, 184950 (2006) (emphasizing this point); Akhil Reed Amar, The Bill of Rights: Creation and Reconstruction 34-45 (Yale 1998) (same); Elk Grove, 542 US at 50 (Thomas concurring) (arguing that "the Establishment Clause is best understood as a federalism provision-it protects state establishments from federal interference but does not protect any individual right"). Yet there several reasons to believe that my proposal is fully compatible with an original public meaning approach to the Establishment Clause. First, although the Founding generation very likely understood the Establishment Clause as applying only to the federal government, the historical evidence is clear that the clause was more than just a protection for state establishments. On the contrary, as Professor Donald Drakeman has persuasively shown, whatever else the clause accomplished, it provided a substantive limit: Congress could not establish a national religion or a national church. See Donald L. Drakeman, Church, State, and Original Intent 229-49 (Cambridge 2010). And the historical evidence-especially the debate in the first Congress over the Uniform 
The Supreme Court has said that, although accommodations are generally permissible under the Establishment Clause, they must not "devolve into 'an unlawful fostering of religion." "212 But the Court has not been clear about how that line ought to be drawn. My claim is that the principles drawn from Madison's and Jackson's arguments offer attractive rules for implementing that limit and a more convincing way of reading the Court's cases than an approach that foregrounds third-party harm.

1. Selective subsidies for favored religious messages.

Let's begin with the principle, drawn from Madison's Memorial and Remonstrance, that government may not foster religious conformity by using religious accommodations to selectively subsidize its favored religious messages. Although the Court has not explicitly relied on Madison's argument in its case law, that argument nonetheless provides an attractive principle for organizing several of the Court's cases.

In Texas Monthly, Inc $v$ Bullock, ${ }^{213}$ for instance, the Supreme Court held that a law providing sales tax exemptions for religious publications violated the Establishment Clause. ${ }^{214}$ Writing for three members of the Court, Justice Brennan attempted to argue that the accommodation violated the Establishment Clause by "increasing the[] tax bills" of nonqualifying taxpayers in order to subsidize religious publications, thus "burden[ing] nonbeneficiaries markedly." ${ }^{15}$ Yet as even proponents of the third-party thesis concede, the idea that the exemption actually affected anyone's tax bill is implausible in the extreme. ${ }^{216}$ What is more, as we have already observed, the Supreme Court has approved a multitude of religious accommodations that involve taxpayer

Militia Act-suggests that this substantive limit included some constraints on religious accommodations. Moreover, even accepting that as an original matter the Establishment Clause applied only to the federal government, there is significant historical evidence suggesting that by the time of Reconstruction, the substantive constraints of the Establishment Clause were also assumed to be part of the "privileges or immunities" guaranteed to all citizens by the Fourteenth Amendment. See Kurt T. Lash, The Second Adoption of the Establishment Clause: The Rise of the Nonestablishment Principle, 27 Ariz St L J 1085, 1141-45 (1995) (making this argument).

212 Amos, 483 US at 334-35, quoting Hobbie v Unemployment Appeals Commission of Florida, 480 US 136, 145 (1987).

213489 US 1 (1989).

214 Id at 5 (Brennan) (plurality).

215 Id at 15, 18-19 n 8 (Brennan) (plurality).

216 See Gedicks and Van Tassell, 49 Harv CR-CL L Rev at 367-68 n 114 (cited in note 23$)$. 
dollars, many of which almost surely increase costs for a specific subset of individuals. ${ }^{217}$

But Texas Monthly is eminently defensible on other grounds. Texas's statute explicitly limited the sales tax exemption to "[p]eriodicals that are published or distributed by a religious faith and that consist wholly of writings promulgating the teaching of the faith." 218 That requirement undoubtedly implicated core free speech principles insofar as it authorized government to discriminate between publications on the basis of content. ${ }^{219}$ But as Justice Harry Blackmun and Justice O'Connor correctly sensed but did not correctly explain, the law also worked a freestanding Establishment Clause harm. ${ }^{220}$ By applying the accommodation only to writings "promulgating the teaching of [a] faith," 221 the law granted an exemption based not on the existence of a religious burden but instead on the $s u b$ stance of a specific religious message. And structuring an accommodation that way allows the government to use accommodations to pick and choose the religious messages it favors.

217 See notes 139-41. See also Volokh, 46 UCLA L Rev at 1513-14 n 154 (cited in note 138).

218 Texas Monthly, 489 US at 5 (Brennan) (plurality), quoting Tex Tax Code Ann $\S 151.312$ (1982).

219 See id at 25-26 (White concurring in the judgment) (arguing that the sales tax exemption violated the Press Clause).

220 Justice Blackmun argued that the statute violated the Establishment Clause because it failed to include "philosophical literature distributed by nonreligious organizations devoted to such matters of conscience as life and death, good and evil, being and nonbeing, right and wrong." Id at 27-28 (Blackmun concurring in the judgment). But the Court has repeatedly held that it is perfectly permissible for accommodations to single out religion. See, for example, Amos, 483 US at 338 (declaring in reference to accommodations that, "[w]here ... government acts with the proper purpose of lifting a regulation that burdens the exercise of religion, we see no reason to require that the exemption comes packaged with benefits to secular entities"); Cutter, 544 US at 724 (reaffirming that view). To be sure, one might argue-as Justice Blackmun and Justice Brennan did-that the exemption in Texas Monthly was not actually an accommodation but instead a generic subsidy that is constitutional only when it includes both religious and nonreligious beneficiaries. See, for example, Walz v Tax Commission of the City of New York, 397 US 664, 673 (1970) (holding that general tax exemptions for churches are constitutional in part because they are "within a broad class of property owned by nonprofit, quasi-public corporations which include hospitals, libraries, playgrounds, scientific, professional, historical, and patriotic groups" that the state considers "beneficial and stabilizing influences in community life"). But that argument overlooks the fact that, unlike general tax exemptions, the exemption in Texas Monthly was designed to relieve a direct burden on religious practice-namely, taxing citizens for evangelistic activities that many understand to be a matter of religious obligation.

221 Texas Monthly, 489 US at 5 (Brennan) (plurality), quoting Tex Tax Code Ann $\S 151.312$ (1982). 
To understand the point, imagine two different Catholic publications-one supporting the church's teaching about an allmale priesthood and another opposing it based on a competing view about the proper interpretation of Catholic doctrine. As a matter of course, Texas's sales tax regime would place an identical burden on the religious practice associated with both publications-citizens would be taxed for engaging in what they believed to be proclamation of the true faith. But under the plain language of the exemption in Texas Monthly, there's good reason to believe that only the first publication was actually eligible for the exemption: after all, that's the publication promulgating the teaching of a faith. ${ }^{222}$ And even if one were to disagree on the facts of that example, it is clear that the statute's design authorized the government to grant accommodations only when it judged a claimant to espouse the particular religious message described in the statute. ${ }^{223}$ The Court in Texas Monthly rightly concluded that an accommodation structured in that fashion is unconstitutional. It gives government the power to encourage conformity by channeling accommodations only to claimants espousing its preferred religious ideas.

To be sure, there is a difference between exemptions like the one at issue in Texas Monthly and the one that Madison condemned in his Memorial and Remonstrance. Unlike Virginia's General Assessment, the Texas exemption selectively subsidized a generic religious message rather than the messages of particular Christian denominations. But that fact makes little difference. The reason is simple: although Madison's argument arose in the context of an accommodation discriminating among Christian sects, his argument was not limited to that context. Madison objected to the exemption in the assessment not just because it offered Quakers and Mennonites preferential treatment compared to other Christian denominations but because it served as a form of government-backed thought control-a

222 Texas Monthly, 489 US at 20 (Brennan) (plurality) (observing that the statute's plain language "require[d] that public officials determine whether some message ... is consistent with 'the teaching of the faith"').

223 The Texas Comptroller's Office tried to assuage that concern by simply ignoring the statute's requirement and creating a policy that allowed religious publishers to determine for themselves whether their publication qualified for the exemption. See id at 20-21 n 9. But as Justice Brennan correctly observed, that informal policy was both contrary to the statute's plain text and subject to change at any time as a matter of administrative discretion. Id. 
means "by which proselytes may be enticed." 224 And that logic applies with equal force to any accommodation that allows the government to skew the marketplace of religious ideas toward its preferred orthodoxy, even an orthodoxy not associated with any single denomination.

Understanding Texas Monthly in light of Madison's argument is also illuminating for another reason: it reconciles the case with wider free speech doctrine. In Rosenberger $v$ Rector and Visitors of University of Virginia, ${ }^{225}$ the Supreme Court held that when the government offers subsidies for private speech on particular topics, it may not exclude religious speech on those same topics simply because the speech contains an evangelistic message. ${ }^{226}$ Critics of Rosenberger have argued that the decision is in tension with anti-establishment values because it sanctioned the direct funding of private religious speech. ${ }^{227}$ But a correct reading of Texas Monthly suggests that, in cases involving private speech, the primary Establishment Clause concern is not "harm" to taxpayer conscience, much less funding for religion. Rather, the concern is with attempts to manipulate the public's religious views to mirror the government's own view. Reading Texas Monthly in light of Madison's argument clarifies that-in both accommodation cases and funding cases involving private speech-it is government-induced conformity, not paying for religion, that the Establishment Clause aims to prevent.

Consistent with Madison's argument in the Memorial and Remonstrance, then, Texas Monthly stands for the proposition that the Establishment Clause condemns accommodations that provide selective subsidies for a preferred religious message. But the principle also extends to other kinds of efforts on the part of government to enhance the religious messages it favors. Here, the important example involves the Court's rulings in some of its first accommodation cases about release-time programs in public schools.

224 Madison, Memorial and Remonstrance at 57 (cited in note 79).

225515 US 819 (1995).

226 Id at $842-46$.

227 See id at 868 (Souter dissenting) (arguing that the Establishment Clause prohibits "[u]sing public funds for the direct subsidization of preaching the word"). See also, for example, Tebbe, Religious Freedom in an Egalitarian Age at 189 (cited in note 23) (arguing that "commitments to ... nonestablishment" were a valid reason for denying funding in Rosenberger). 
In McCollum v Board of Education, ${ }^{228}$ the Court struck down an accommodation that would have allowed public school students to be released from class to receive religious instruction on school grounds. ${ }^{229}$ Although the instruction was voluntary and required parental consent, the Court nonetheless held that the program violated the Establishment Clause. ${ }^{230}$ But just a few years later in Zorach $v$ Clauson,231 the Court upheld a similar release-time program in which the religious instruction took place off school grounds. ${ }^{232}$

The reasoning in these cases is opaque. In McCollum, the majority suggested that use of the state's "tax-established and tax-supported public school system" rendered the program unconstitutional. ${ }^{233}$ But that argument-like the plurality's argument in Texas Monthly-relies on unpersuasive claims about taxpayer harm. Other justices suggested that the key element in the cases involved the harm that release-time programs caused nonparticipating students. ${ }^{234}$ But that claim also seems overdrawn, at least as a doctrinal matter. Providing students with an hour of study hall while some of their peers engage in religious instruction does not seem like a constitutionally significant imposition-especially because the religious students undoubtedly still had to complete all the same assignments as their peers.

Here too, Madison's argument against selective subsidies for favored religious messages provides the most convincing rationale for the Court's decisions. As Justice Brennan later observed, the Court's attempt to explain McCollum by reference to public expenditures was wholly unconvincing-using "classrooms, heat and light and time" simply does not add any real cost for anyone nor would such a cost even be relevant. ${ }^{235}$ Instead, what distinguished the release-time program in McCollum from the program in Zorach was the fact that the former "len[t] ... sectarian instruction all the authority of the

228333 US 203 (1948).

229 Id at $211-12$.

230 Id at 207-08.

231343 US 306 (1952).

232 Id at 315.

233 McCollum, 333 US at 210.

234 See, for example, Zorach, 343 US at 324 (Jackson dissenting) (arguing that the release-time program "serve[d] as a temporary jail for a pupil who will not go to Church").

235 Schempp, 374 US at 261 (Brennan concurring). 
governmentally operated public school system" 236 while giving school officials unbridled discretion to deny those benefits to disfavored religious messages. By holding the release-time program in the regular public school classrooms, the McCollum program effectively underwrote the authority of religious teachers by "plac[ing] [them] ... in precisely the position of authority held by the regular teachers of secular subjects."237 But even more importantly, it left the decision about which religious groups could participate solely to the school superintendent, who would "determine whether or not it [was] practical for said group to teach in said school system." ${ }^{238}$ By contrast, the program in Zorach allowed any "duly constituted religious body" to conduct offsite instruction, and prohibited all school officials from "comment[ing] ... on attendance or nonattendance of any pupil." 239 Madison's argument in the Memorial and Remonstrance dealt only with monetary subsidies. But the insight of the Court's release-time cases is that the Establishment Clause also prohibits accommodations that grant the government unfettered discretion to use its "prestige and capacity for influence" 240 to promote some religious ideas over others.

In sum, although the Court's precedents have not always been clear in explaining the point, modern Establishment Clause doctrine echoes Madison's argument in the Memorial and Remonstrance. Although accommodations are generally permissible, the Establishment Clause prohibits accommodations that foster religious conformity by selectively subsidizing the government's preferred religious messages. But that is not all. The Court's precedents-like Jackson's argument about the militia accommodation-also suggest a second limit focused on incentives.

2. Incentives to adopt the accommodated religion.

The second principle, drawn from Jackson's argument about the Uniform Militia Act, suggests that the Establishment Clause limits accommodations that create exceedingly powerful

\footnotetext{
236 Id at 263 (Brennan concurring).

237 Id at 262 (Brennan concurring).

238 McCollum, 333 US at 208 n 3.

239 Zorach, 343 US at $308 \mathrm{n} 1$.

240 Schempp, 374 US at 263 (Brennan concurring).
} 
incentives to adopt the accommodated religion. ${ }^{241}$ Like Madison's argument, this limiting principle has not always been clearly articulated by the Court. Nonetheless, it illuminates several other cases setting limits on religious accommodations, including some invoked by supporters of the third-party thesis.

To unpack the point, let's return to the Supreme Court's famous Draft Cases, which involved exemptions from combat service during the Vietnam War. In United States $v$ Seeger, ${ }^{242}$ the Court considered an Establishment Clause challenge to the Selective Service Act. ${ }^{243}$ The Act allowed individuals "conscientiously opposed to participation in war in any form" to obtain an exemption, provided their objection was based on "religious training and belief." ${ }^{244}$ The law further defined "religious belief" as a belief concerning "a Supreme Being involving duties superior to those arising from any human relation" rather than "essentially political, sociological, or philosophical views." 245

Daniel Seeger applied for an exemption but was denied after stating that his objection was based on "a religious faith in a purely ethical creed." 246 The Supreme Court reversed. The Court reasoned that the law's reference to beliefs involving a "Supreme Being" should be interpreted broadly to include any belief that "occup[ies] the same place in the life of the objector as an orthodox belief in God." 247 According to the Court, because Seeger's beliefs occupied a "parallel position[]" to beliefs associated with traditional religion, he was eligible for the exemption. ${ }^{248}$

Just a few years later in Welsh $v$ United States, ${ }^{249}$ the Court widened its reading of the Selective Service Act even further. Like Seeger, Elliott Welsh maintained that he was agnostic as to the existence of God. Unlike Seeger, however, Welsh emphatically rejected the characterization of his beliefs as "religious." Instead, he claimed that his opposition to war stemmed from a belief that

241 This principle shares much in common with a view of the Religion Clauses focused on "substantive neutrality." See Douglas Laycock, Formal, Substantive, and Disaggregated Neutrality toward Religion, 39 DePaul L Rev 993, 1017 (1990) (exploring the problem of incentives in relation to military service); Laycock, 81 Notre Dame L Rev at 1808 (cited in note 150) (same).

242380 US 163 (1965).

24362 Stat 604 (1948), codified at 50 USC $\S 3801$ et seq.

244 Seeger, 380 US at 165, citing 50 USC App § 456(j) (1958).

245 Seeger, 380 US at 165, quoting 50 USC App § 456(j) (1958).

246 Id at 166.

247 Id at 184

248 Id at 166 .

249398 US 333 (1970) (Black) (plurality). 
"human life is valuable in and of itself." 250 The Supreme Court nonetheless held that Welsh was also entitled to the exemption. Glossing over the statute's explicit refusal to grant exemptions based on "political, sociological, or philosophical views," a plurality of the Supreme Court held that the statute mandated an exemption for any opposition to war arising from "deeply held moral, ethical, or religious beliefs." 251

As a matter of statutory interpretation, the reasoning in Seeger and Welsh is exceedingly dubious. Accordingly, many commentators view these cases as rooted in the Establishment Clause. Yet if that is so, what kind of Establishment Clause rule did the Draft Cases actually announce? One possibility might be that the Establishment Clause forbids singling out "religion" for accommodation, rather than also accommodating all equivalent moral or philosophical convictions. ${ }^{252}$ But that explanation is improbable. For one thing, only Justice John Marshall Harlan adopted anything like this view. ${ }^{253}$ But even more importantly, that interpretation stands at odds with the Court's repeated insistence that a religious accommodation need not "come packaged with benefits to secular entities" to comply with the Establishment Clause. ${ }^{254}$

Jackson's argument about incentives provides a much more plausible explanation. By denying an exemption from combat service to everyone but religious pacifists, the Selective Service Act clearly created an inducement to adopt the required religion. First, the nature of the material benefit-avoiding the perils of war and maintaining basic bodily security-is itself an objectively powerful inducement. And given that the stigma surrounding pacifism has decreased from the Founding era to today, it seems reasonable to view that inducement as equivalent to a coercive law, even absent an accompanying monetary incentive. ${ }^{255}$

250 Id at 343 (Black) (plurality).

251 Id at 344 (Black) (plurality).

252 See Micah Schwartzman, What If Religion Is Not Special?, 79 U Chi L Rev 1351, 1367 n 62, 1417-18 (2012) (arguing in favor of this interpretation); William P. Marshall, The Case against the Constitutionally Compelled Free Exercise Exemption, 40 Case W Res L Rev 357, 396 n 189 (1989) (same). For an interesting and sophisticated theory defending this approach to the Religion Clauses generally, see Christopher L. Eisgruber and Lawrence G. Sager, Religious Freedom and the Constitution 112-18 (Harvard 2007).

253 See Welsh, 398 US at 356-61 (Harlan concurring).

254 Amos, 483 US at 338. See also Cutter, 544 US at 724.

255 Compare Philip A. Hamburger, Religious Freedom in Philadelphia, 54 Emory L J 1603, 1609 (2005) (observing that during the Founding period "Quakers, Mennonites, and other pacifists found themselves at the mercy of resentful mobs ... who occasionally 
Moreover, like the Founding-era exemption, the exemption in the Selective Service Act involved deep claims of conscience about particular topics-unjust killing and participation in war generally-that members of the first Congress recognized as deeply powerful in their own day and that we recognize as similarly powerful in ours. ${ }^{256}$ Finally, the Court chose to solve the problem by applying exactly the remedy Jackson and others suggested-namely, dissipating the incentive toward religious conformity, in this case by widening the exemption. The reasoning in the Draft Cases is obscure. But read in the most persuasive way possible, they echo Jackson's theory exactly: when an accommodation provides exceptionally powerful incentives to adopt the religion being accommodated, the Establishment Clause demands that it be modified to dispel the inducement.

To be sure, the Draft Cases might seem a fragile basis for suggesting that modern Establishment Clause doctrine limits accommodations that provide exceptionally powerful incentives to adopt a religion. But many parts of the law consistently take this same shape, expanding accommodations that involve a similar combination of strong material incentives and weighty matters of conscience. For example, the law protects employees in state and federal prisons from disciplinary action for refusing to engage in virtually any form of participation in the death penalty that is "contrary to th[eir] moral or religious convictions." ${ }^{257}$ Similar protections exist for health care providers whose "religious beliefs or moral convictions" prohibit them from performing sterilizations or abortions. ${ }^{258}$ Likewise, all six states

educated their fellow Americans as to the cost of ignoring their civic duties"), with Bill Zimmerman, The Four Stages of the Antiwar Movement (NY Times, Oct 24, 2017), online at http://www.nytimes.com/2017/10/24/opinion/vietnam-antiwar-movement.html (visited Mar 26, 2019) (Perma archive unavailable) (noting that by 1967, a protest against the war in Vietnam attracted no fewer than 500,000 people, and "[s]elf-interested draft avoidance evolved into morally driven draft resistance").

256 For example, Representative Roger Sherman observed that "persons conscientiously scrupulous of bearing arms could not be compelled to do it; for such persons will rather suffer death than commit moral evil." 2 Annals of Congress 1872 (Dec 22, 1790).

25718 USC § 3597(b) (providing that "[n]o employee ... shall be required . . . to be in attendance at or to participate in any prosecution or execution under this section if such participation is contrary to the moral or religious convictions of the employee," and specifying that "participation" includes "personal preparation of the condemned individual and the apparatus used for execution and supervision of the activities of other personnel in carrying out such activities"). See also Mark L. Rienzi, The Constitutional Right Not to Kill, 62 Emory L J 121, 139-42 (2012) (discussing this provision and similar state laws).

25842 USC § 300a-7(b) (also known as the "Church Amendment"). Similarly, the Affordable Care Act prohibits the government from discriminating in its qualified health 
that currently permit physician-assisted suicide provide protection for physicians who refuse to participate, whether their objections are religious or not. ${ }^{259}$ And those examples again mirror the draft example: they involve an objectively powerful incentive-here, losing one's job-and also claims of conscience that are both deeply powerful and widely held. And although the connection to the Establishment Clause is only implicit, the fact that the law already avoids inducements toward religious conformity in instances like these is highly suggestive.

But how far does the principle extend? After all, read in a less nuanced way, Jackson's concern with the Quaker exemption could be seen as focused not on things like bodily security or the moral weightiness of war but instead only on the "pecuniary advantages" that would result from excusing Quakers from paying for a substitute. 260 And indeed, in response to the Court's decision in Hobby Lobby, several commentators raised a similar concern, claiming that the "financial incentive" to avoid regulation created by the Court's decision would encourage many corporations to become religious in order to avoid various costs. ${ }^{261}$

Undoubtedly, the worry over financial incentives is appropriate. After all, massive economic incentives can certainly be a potentially potent tool in fostering conformity. Yet there are also

plans against "any individual health care provider or health care facility because of its unwillingness to provide, pay for, provide coverage of, or refer for abortions." 42 USC $\S 18023(\mathrm{~b})(4)$. See also 42 USC $\S 18023(\mathrm{c})(2)(\mathrm{A})$ (expressly stating that nothing in the Affordable Care Act shall be construed to have any effect on federal laws regarding conscience protection and "willingness or refusal to provide abortion").

259 See Cal Health \& Safety Code $§ 443.14(\mathrm{e})(1)-(2)$ (providing a right not to participate in physician-assisted suicide to "a person or entity that elects, for reasons of conscience, morality, or ethics," including a right to refuse to inform patients of the practice or refer them to physicians who engage in it); Colo Rev Stat Ann § 25-48-117(1)-(2) (providing that, when a health care provider is "unable or unwilling to carry out an individual's request for medical aid-in-dying," she may refuse); Hawaii Rev Stat § 327L19(a)(4) (providing that no health care provider or facility "shall be under any duty, whether by contract, statute, or any other legal requirement" to provide medication to end a patient's life); Or Rev Stat Ann $§ 127.885$ (same); 18 Vt Stat Ann § 5285(a)-(b) (providing that no person shall be "under any duty ... to participate in the provision of a lethal dose of medication," nor can they be disciplined by any health care facility or provider for refusal to do so); Wash Rev Code Ann $§ 70.245 .190(b)$, (d) (providing that "[o]nly willing health care providers shall participate in the provision to a qualified patient of medication to end his or her life" and providing various other protections).

2602 Annals of Congress 1872 (Dec 22, 1790).

261 Marshall, 2014 S Ct Rev at 120 (cited in note 4). See also Leslie C. Griffin, Hobby Lobby: The Crafty Case That Threatens Women's Rights and Religious Freedom, 42 Hastings Const L Q 641, 674 (2015) (arguing that "Hobby Lobby open[ed] the door for corporate RFRA claims, thus expanding the possibilities for religious exemptions in corporate America"). 
good reasons to approach arguments focused exclusively on financial incentives with care. For one thing, it is easy to overestimate the influence that supposed monetary benefits will exert over potential claimants. Contrary to the fears expressed after Hobby Lobby, there is now mounting empirical evidence that the Court's ruling did not actually produce the tidal wave of followon religious liberty claims that critics predicted. ${ }^{262}$ Indeed, there is even evidence that, in the months and years following Hobby Lobby, the number of religious liberty cases being brought actually declined. ${ }^{263}$ If strong financial incentives to challenge wide swaths of regulation were actually created by the Hobby Lobby ruling, one would expect to see different results.

There is also a subtler point here. Financial incentives can appear powerful, especially when considered in isolation. But that perspective can obscure the ways that those incentives, even significant ones, are frequently overshadowed by other concerns. Seeking a religious exemption from employment regulations or other laws might offer modest cost-savings in theory. But it also risks alienating one's workforce, sparking public controversy, and weathering robust inquiries into the sincerity of one's beliefs. Moreover, unlike the draft example, in these cases there is no temptation to feign religion to avoid what might seem to be an even more egregious moral wrong. On the contrary, in cases involving only financial incentives, concerns about conscience cut decidedly the other way. And given all of that, the relative paucity of corporate religious liberty litigation after Hobby Lobby is unsurprising. When the social and moral costs of seeking a religious accommodation are high-as they almost always are-the idea that financial incentives alone will be sufficient to raise Establishment Clause worries can be overdrawn. ${ }^{264}$

\footnotetext{
262 See Goodrich and Busick, 48 Seton Hall L Rev at 356, 384 (cited in note 10) (documenting RFRA claims in the Tenth Circuit and concluding that such cases "remain scarce" and that there were no new RFRA challenges "by any for-profit corporations-or any organization for that matter" thirty-two months after Hobby Lobby); Barclay and Rienzi, 59 BC L Rev at 1642 (cited in note 10) (noting that an empirical assessment of the federal caseload shows that religious freedom claims have remained "fairly constant").

263 See Barclay and Rienzi, 59 BC L Rev at 1643 (cited in note 10) (documenting a decline in religious liberty cases as a percentage of the reported federal cases following Hobby Lobby).

264 See Nathan S. Chapman, Adjudicating Religious Sincerity, 92 Wash L Rev 1185, 1232-33 (2017) (noting "the costs-financial, emotional, and otherwise-entailed in ... seek[ing] a religious accommodation," and observing that "[t]he specter of litigation alone could deter the fainthearted, much less the false"). In this sense at least, Madison may
} 
A more promising approach would focus less on money and more on situations in which government has powerful tools to encourage conformity by exerting significant control over day-today life. And indeed, courts have already recognized as much in contexts like prisons. In Cutter, the Supreme Court noted that, although religious accommodations for prisoners are generally constitutional under the Establishment Clause, there is nonetheless cause for concern when "the opportunity to assemble in [prison] worship services, might attract joiners seeking a break in their closely guarded day." 265 Accordingly, lower courts have sometimes augmented religious accommodations to allow atheists or secular humanists to form clubs on similar terms with religious groups. ${ }^{266}$ Likewise, courts have also extended Cutter's observation to other contexts by concluding that the Establishment Clause requires prison officials to refrain from attaching valuable benefits, such as early release or "good time" credits, to participation in religious treatment programs, at least when a secular alternative is unavailable. ${ }^{267}$

But what about instances in which the Court has held an accommodation is permissible or even required despite the fact that it could be seen as creating incentives for religious practice? In Amos, for instance, the Court unanimously upheld Title VII's exemption allowing religious organizations to hire only members of their own religion despite the fact that it might entice present or future employees to comply with a church's teachings. 268 Likewise, one might suggest that the ministerial exception at issue in Hosanna-Tabor incentivizes religious leaders to behave according to their church's beliefs. ${ }^{269}$ Why, then, doesn't the Establishment Clause prohibit it?

The answer, quite simply, is that Amos and Hosanna-Tabor do not stand at odds with the concern over religious incentives.

have had the better of the argument over the Quaker exemption. See 2 Annals of Cong 1872 (Dec 22, 1790) (silently accepting Jackson's proposed connection between religious establishment and induced conformity, but arguing that citizens would not "renounce their principles, their conscience, and their God" for the sake of modest monetary advantages).

265 Cutter, 544 US at $721 \mathrm{n} 10$.

266 See, for example, Kaufman v McCaughtry, 419 F3d 678, 683-84 (7th Cir 2005).

267 See generally, for example, Griffin v Coughlin, 673 NE2d 98 (NY 1996) (family visitation); Kerr v Farrey, 95 F3d 472 (7th Cir 1996) (consideration for parole); Munson $v$ Norris, 435 F3d 877, 880-81 (8th Cir 2006) (extra work detail); Warner v Orange County Department of Probation, 115 F3d 1068 (2d Cir 1996) (probation).

268 Amos, 483 US at 339-40.

269 See generally Hosanna-Tabor, 565 US 171 (2012). 
On the contrary, they validate it. But they do so by relating that concern to larger worries over government-induced religious conformity.

To understand the point, the best place to begin is Amos. It is true that allowing religious organizations to discriminate in their hiring might occasionally result in an inducement for a potential employee to adopt or feign a religion. But unlike exemptions from the draft or similar examples, the inducement is not triggered by government action. Rather, as the Court in Amos correctly observed, the decision to leave religious organizations with discretion about whom to hire and fire simply removes government control-any subsequent incentive is the result of contingent action by a private group, not action by the government. 270 But even if one disagrees, there is also a deeper insight here. Situations like those in Amos present a choice: either allow legislatures to exempt religious organizations knowing that doing so might unintentionally alter the choices of a few employees, or face a regime in which all religious groups must repeatedly litigate which of their positions are "religious" and which are not.271 And not surprisingly, when faced with that choice, every single justice in Amos opted to uphold the exemption. That approach is the one less likely to foster control over religious practice and the one that actually reduces governmental incentives to conform in the mine run of cases.

The argument is even stronger when one considers HosannaTabor, which held that the Religion Clauses prohibit courts from entertaining certain kinds of employment lawsuits involving a religious organization and its leaders. As in Amos, there was a sense in which that approach might create an incentive insofar as it put clergy on notice that failure to adhere to their church's doctrine might lead to termination without legal recourse. But again, that incentive is not of the government's own making: a church's decision about whom to retain as its minister is one of the clearest examples of private action one could imagine. Moreover, the worry that the ministerial exception might incentivize religious leaders to comply with their church's teaching-if that

270 Amos, 483 US at $337 \&$ n 15 (observing that the employee in the case had his "freedom of choice in religious matters ... impinged upon," but that "it was the Church ... not the Government" who exerted that pressure by terminating him from his job).

271 As Justice Brennan observed, that regime would "chill[] religious activity" by inducing religious groups to organize themselves in ways that minimize their litigation risk rather than maximize their faith. Amos, 483 US at 345 (Brennan concurring). 
even counts as a worry272-pales in comparison to the risks associated with giving government the power to effectively select a church's ministers. Church autonomy decisions like those in Amos and Hosanna-Tabor further the Establishment Clause concern over incentives by providing more latitude for religious choice, not less.

Policing accommodations that create powerful incentives is an important part of the Establishment Clause. But it is also part of a much broader goal: preventing government from deciding what kind of religion the populace will or will not practice. It is that evil, above all others, that the Establishment Clause is intended to prevent.

\section{RECONSIDERING HARM}

At this point, it is worth briefly recapitulating the argument as it stands so far.

First, I have argued that, although the third-party thesis is relatively popular among academics and perhaps even gaining ground among a few members of the Supreme Court, there are good reasons to believe it fails as an interpretation of the Establishment Clause. Its analogy between accommodations that inadvertently generate costs and church taxes is both historically and conceptually weak, and the thesis is foreclosed by many of the Court's precedents.

Second, I have argued that, when evaluating religious accommodations under the Establishment Clause, the fundamental inquiry ought to be whether the government is using its power to foster religious conformity. Under that principle, the Establishment Clause prohibits accommodations that selectively favor the government's preferred religious messages as well as accommodations that provide exceedingly powerful incentives to adopt the religion being accommodated. Those limits provide satisfying explanations for many of the Supreme Court's precedents, and they ground Establishment Clause analysis in an

272 See Christopher C. Lund, Free Exercise Reconceived: The Logic and Limits of Hosanna-Tabor, 108 Nw U L Rev 1183, 1194 (2014):

When one joins a church, one accepts the religious choices made by the church. People can leave or stay. But so long as they choose to stay, they accept how the church handles its religious affairs. Dissenters cannot use the coercive force of the government to compel a change in the church's religious views, practices, or governance. 
approach that is more historically and doctrinally plausible than one that emphasizes third-party harm.

But my position is open to some significant objections. Most importantly, some readers will surely worry that my view of the Establishment Clause is too narrow and perhaps even dangerously so. If the Establishment Clause is fundamentally a prohibition on government-induced conformity, what are we to do with accommodations that threaten other interests in important ways? To take just one obvious example, what about an accommodation from homicide laws for a religious group that engages in ritual killings? Such a law seems unlikely to induce others toward religion. But if the Establishment Clause is best read as a ban on attempts to induce religious conformity, does that mean the Constitution has nothing to say about this fanciful law-and others like it-when the harms are striking?

These concerns are real. But more than that, I think that, as a matter of substance, they are well founded. There are and should be limits on laws that harm others, and religious accommodations are no exception. But objections like these tacitly assume that an Establishment Clause principle focused squarely on third-party harm is the only possible source of those limits. That assumption is false. Indeed, as this Part explains, viewing the Establishment Clause as a ban on governmentinduced conformity does not mean ignoring the costs of accommodation. On the contrary, it actually provides a more plausible way of thinking about such costs and the various ways that the law limits them. This Part explains that insight first in relation to the Establishment Clause and goes on to discuss other limits on religious accommodation.

\section{A. The Establishment Clause}

To begin, let's return to the most basic point. Although accommodations are generally permissible under the Establishment Clause, the Supreme Court has said they must not "devolve into 'an unlawful fostering of religion." 273 As we have seen, that rule is clearly violated when accommodations provide unfair advantages for the government's favored religious ideas or create powerful incentives to engage in religious practice. But there are also subtler forms of manipulation. Most obviously, government may unlawfully foster religious conformity 
by using accommodation as a pretext to reward those who have already chosen to conform.

Recall that as a historical matter, religious accommodations have always been coextensive with disestablishment: they remove government power over private religious practice and thereby serve the larger goal of preserving religious freedom. But it is important to remember that not all exceptions for religion fell into that category. In medieval England, "benefit of clergy" exemptions allowed leaders of the established church to avoid prosecution in civil courts for serious crimes, including murder and rape. ${ }^{274}$ In colonial New York and elsewhere, the established church possessed special legal privileges allowing it to hold property while other churches could not. ${ }^{275}$ In Virginia, ministers of the Church of England who wished to conduct marriages were exempted from licensing requirements that applied to all other groups, ${ }^{276}$ and so on.

The point here is a simple one: there is an important difference between exemptions protecting religious freedom and exemptions designed to favor or reward religious people of one sort or another. Genuine accommodations are aimed at alleviating burdens on religious practice and thus are part of the broader project of ensuring religious liberty for all. But some exemptions serve the opposite function-they grant privileges or benefits not to relieve a burden but instead simply to reward the government's preferred form of religiosity. And as the Court's modern cases suggest, one important factor in distinguishing these kinds of laws from constitutionally permissible accommodations involves their redistributive effects.

To see what I mean, let's return to Caldor, the case most often invoked by supporters of the third-party thesis. There, the Supreme Court considered an Establishment Clause challenge to a Connecticut law guaranteeing that no person could be required to work on a day designated as his Sabbath. ${ }^{277}$ Donald Thornton, a manager at a department store, sought an accommodation under the statute after his employer began

274 See Berg, 38 Harv J L \& Gender at 144-47 (cited in note 77) (describing these laws). 275 See Mark D. McGarvie, Disestablishing Religion and Protecting Religious Liberty in State Laws and Constitutions (1776-1833), in T. Jeremy Gunn and John Witte Jr, eds, No Establishment of Religion: America's Original Contribution to Religious Liberty 70, 90-91 (Oxford 2012) (describing these laws).

276 See McConnell, $44 \mathrm{Wm} \&$ Mary L Rev at 2175-76 (cited in note 150) (explaining licensing regimes for conducting marriages).

277472 US at 706. 
opening its stores on Sunday. His employer argued that the accommodation violated the Establishment Clause, and the Supreme Court agreed. 278

Supporters of the third-party thesis focus on Chief Justice Burger's observation about the "significant burdens" the law placed on employers and employees as the dispositive feature of the case.279 But as we have already seen, the Court has repeatedly blessed accommodations that generate costs for others.280 Moreover, a focus on harm alone is also a poor fit on Caldor's own facts. Prior to the Sabbath law, Thornton's employer had already adopted an internal policy that granted almost all of its employees the right to refrain from Sunday work if such work was "contrary [to the employee's] personal religious convictions." 281 Admittedly, Thornton was a manager, not a generic employee. But there was no evidence that alternatives like finding a substitute had even been tried, much less found wanting. Harm alone is not a sufficient basis to explain the decision.

Now consider the case in a more holistic way. The law at issue in Caldor provided a day off for anyone "who state[d] that a particular day of the week is observed as his Sabbath." ${ }^{282}$ By its terms, that command extended beyond relieving a burden on religious practice. By providing a day off for anyone who stated that a particular day "is observed" as his Sabbath, the statute also appeared to mandate a full day's absence even when the relevant religious need involved nothing more than attending a worship service lasting a few minutes. ${ }^{283}$ But what is more, the

\footnotetext{
278 Id at $710-11$.

279 Id at 710. See, for example, Gedicks and Koppelman, 67 Vand L Rev En Banc at 54 (cited in note 114). They also point to Chief Justice Burger's statement-taken from Judge Learned Hand-that "[t]he First Amendment . . . gives no one the right to insist that in pursuit of their own interests others must conform their conduct to his own religious necessities." Caldor, 472 US at 710, quoting Otten v Baltimore \& Ohio Railroad Co, 205 F2d 58, 61 (2d Cir 1953). See also Tebbe, Religion in an Egalitarian Age at 55 (cited in note 23); Gedicks and Van Tassell, 49 Harv CR-CL L Rev at 358 (cited in note 23) (same). Yet as others have rightly observed, reading that statement in context casts doubt on the idea it was meant to express concern over generic third-party harm. See, for example, Sepinwall, 82 U Chi L Rev at 1968-69 n 259 (cited in note 4) (explaining that the statement originally stood for the idea that "one cannot claim First Amendment protections against nonstate actors" and was used by Chief Justice Burger to emphasize the law's "formal favoring of religious interests," not its impact on third-parties).

280 See notes 114-41 and accompanying text.

281 Caldor, 472 US at $706 \mathrm{n} 4$.

282 Id at 708, quoting Conn Gen Stat § 53-303e(b).

283 See id at 709 (characterizing the law as "arm[ing] Sabbath observers with an absolute and unqualified right not to work on whatever day they designate as their
} 
law required private parties to take affirmative steps to relieve that nonexistent burden even when the costs of doing so were exceedingly high. ${ }^{284}$ The majority in Caldor concluded that Connecticut's Sabbath law amounted to an "unyielding weighting in favor of Sabbath observers,"285 not because it incidentally harmed third-parties but because it provided an unjustified reward for some religious claimants with no regard for the costs that requirement might impose. ${ }^{286}$

A similar logic explains much of the Court's language in Cutter, the other case most frequently cited by supporters of the third-party thesis. In Cutter, the Court upheld RLUIPA, a general accommodation statute that allows prisoners to seek caseby-case religious accommodations for things like kosher food or religious dress. In so holding, the Court observed that RLUIPA requires courts to "take adequate account of the burdens a requested accommodation may impose on nonbeneficiaries." 287 More specifically, the Court noted that the burden-shifting analysis mandated by RLUIPA's text indicated that it would not "elevate accommodation of religious observances over an institution's need to maintain order and safety." 288 Concluding its opinion, however, the Court cautioned that, "[s]hould inmate requests for religious accommodations ... impose unjustified burdens on other[s]," prisons would be right to resist them. ${ }^{289}$

Sabbath"). See also Kent Greenawalt, 2 Religion and the Constitution: Establishment and Fairness 344-45 (Princeton 2008) (observing that the law in Caldor "gave workers their Sabbath off from work whether or not they objected in principle to working on their Sabbath, and could or could not combine worship and work on the same day").

284 See Caldor, 472 US at 709 (suggesting that the law "command[ed] that Sabbath religious concerns automatically control over all secular interests at the workplace" irrespective of "the convenience or interests of the employer or those of other employees"). See also Amos, 483 US at 337-38 \& n 15 (suggesting that the statute in Caldor had "given the force of law to the employee's designation of a Sabbath day and required accommodation by the employer regardless of the burden which that constituted for the employer or other employees").

285 Caldor, 472 US at 710.

286 Admittedly, the Court in Caldor was probably wrong to strike down the Sabbath law rather than dealing with the concern about gratuitous burden-shifting in an asapplied challenge. But that error was part of the Court's larger failure to distinguish between facial and as-applied challenges in its Establishment Clause jurisprudence-a problem it has since remedied. See Bowen v Kendrick, 487 US 589, 602 (1988) (acknowledging the appropriateness of distinguishing between facial and as-applied challenges under the Establishment Clause).

287 Cutter, 544 US at 720.

288 Id at 722 .

289 Id at 726 . 
Proponents of the third-party thesis point to this discussion as evidence of an Establishment Clause rule prohibiting generic harm. ${ }^{290}$ But again, there is a more plausible reading. Cutter held that RLUIPA was constitutional because it both "alleviate[d] . . . burdens on private religious exercise" and "[took] adequate account of the burdens . . . on nonbeneficiaries." ${ }^{291}$ In other words, unlike the Sabbath law in Caldor, laws like RLUIPA and RFRA do not command gratuitous burden-shifting. On the contrary, they mandate accommodations only when a claimant demonstrates a "substantial burden" on her religious exercisean actual conflict between one's religious practice and the policy at issue. ${ }^{292}$ Moreover, even if one might worry about an overbroad reading of that test, these statutes also contain a compelling interest limitation, ensuring that the kind of "unyielding weighting" at issue in Caldor will never arise.293 True, the Court in Cutter cautioned that, if RLUIPA were used to impose "unjustified burdens," the Establishment Clause would prohibit it.294 But the point of that observation, as in Caldor, was about redistribution that is both baseless and costly. Were RLUIPA used as a pretext to command significant cost-shifting unconnected to relieving any burden on religious practice, there is no doubt the Establishment Clause would prohibit it.

Read together, Caldor and Cutter suggest that there is indeed a special Establishment Clause concern arising from accommodations that shift costs. But that concern is not over the

290 See notes 114-16 and accompanying text.

291 Cutter, 544 US at 720. The Court also noted that RLUIPA's text indicated that it would be "administered neutrally among different faiths." Id.

292 See 42 USC $\$ \S 2000$ bb-1(a)-(b), 2000cc-1. To be sure, the question as to how exactly courts ought to approach the substantial burden inquiry is itself an area of vigorous scholarly disagreement. For a few different perspectives, see Ira C. Lupu, Where Rights Begin: The Problem of Burdens on the Free Exercise of Religion, $102 \mathrm{Harv} \mathrm{L}$ Rev 933, 966 (1989) (arguing that a substantial burden occurs when "religious activity is met by intentional government action analogous to that which, if committed by a private party, would be actionable under general principles of law"); Michael A. Helfand, Identifying Substantial Burdens, 2016 U Ill L Rev 1771, 1793 (arguing that courts ought to focus on the "substantiality of the civil penalty"); Chad Flanders, Substantial Confusion about "Substantial Burdens", 2016 U Ill L Rev Online 27, 29 (arguing that a substantial burden on religion involves "the quantum of pressure that is put on a person to violate his religious beliefs - that means any part of his religious beliefs, and for any amount of time").

293 See 42 USC $\S \S 2000 b b-1(a)-(b), 2000 c c-1$. See also Hobby Lobby, 134 S Ct at 2781 n 37 (observing that a concern over "the burdens a requested accommodation may impose on nonbeneficiaries ... will often inform the analysis of the Government's compelling interest and the availability of a less restrictive means of advancing that interest").

294 Cutter, 544 US at 726. 
presence of third-party harm. Rather, it is over the connection between an accommodation's costs and the lifting of an actual burden on religious practice. When claims for accommodation outrun any actual burden on free exercise while also imposing significant costs, there are good reasons to believe they are unjustified attempts to reward a favored religious identity. By contrast, when an accommodation incidentally redistributes costs as part of a transparent effort to protect religious freedom, there is generally no reason to believe it raises any Establishment Clause concern. Rather, it is just one more instance-like accommodations for disability, pregnancy, and so on-in which the law adjusts benefits and burdens to account for things many people care about.

But of course, there is also another potential problem. In most instances, bestowing a gratuitous and costly benefit on a religious claimant will be sufficient evidence that an accommodation is a pretext to reward religious conformity. But what about instances in which a burden on free exercise is actually present, but an accommodation's costs seem radically disproportionate? A religious exemption for a group that engages in human sacrifice would undoubtedly lift a religious burden, but no one would ever think such a carve-out from homicide laws is justified. And indeed, that kind of concern seems at least vaguely implied by Cutter's observation that "an accommodation must be measured so that it does not override other significant interests." ${ }^{995}$ How are we to think about such laws?

One possibility, and the one most closely resembling the third-party thesis, would be to insist that an accommodation is a pretext for favoritism whenever it results in more than a minimal cost, no matter the religious interest at issue. The Court has never endorsed that approach as a matter of Establishment Clause doctrine. But it has sometimes employed it as a matter of statutory interpretation. In Trans World Airlines, Inc $v$ Hardison, ${ }^{296}$ for instance, the Court considered the meaning of Title VII's command that employers provide "reasonable accommodations" for their employees' religious needs. ${ }^{297}$ Notwithstanding the fact that the statute explicitly requires accommodation unless the employer "demonstrates [] he is unable to ...

295 Id at 722 .

296432 US 63 (1977).

297 Id at 69. See also 42 USC $\S 2000 e(j)$. 
[provide them] without undue hardship,"298 the Court insisted that any cost that is "more than ... de minimis" presents such a hardship. ${ }^{299}$ According to the Court, requiring costs above this threshold without "giv[ing] other employees the days off that they want" risked "unequal treatment" on the basis of religion. ${ }^{300}$

The Court's holding in Hardison is dubious for a number of reasons. By definition, de minimis costs are not hardships (much less "undue" hardships), and the statutory context provides no reason to think that Congress meant otherwise. ${ }^{301}$ But even setting this point aside, the Court's reasoning seems callous and wooden. The majority worried that applying Title VII's religious accommodation as written could mean that other employees may not get "the days off that they want." 302 But not all scheduling requests are of similar magnitude. Requesting an absence to observe Yom Kippur or Good Friday is different from a request to attend a beer festival, and it trivializes the former to suggest that they are not. Moreover, the Court's approach to the problem ignored the ways that many employment-related accommodations-for disability, pregnancy, and other things-regularly generate more than de minimis costs. These are the kinds of needs analogous to religious ones in seriousness and importance. Yet the Court in Hardison focused solely on the cost side of the equation with no regard for the significance of the activity being protected or the usual rules applying to such laws.

A more plausible approach to the problem would begin by recognizing that legislatures possess broad discretion to protect important interests, and religious interests are no exception. Yet that discretion is not limitless. Since the Founding, the right to free exercise has always been considered defeasible in the face of exceedingly powerful threats to "private rights or the public peace." 303 Indeed, as Professor Michael McConnell has observed, no fewer than nine state constitutions at the Founding included

298 Hardison, 432 US at 73-74, quoting 42 USC $\S 2000 \mathrm{e}(\mathrm{j})$.

299 Hardison, 432 US at 84.

$300 \mathrm{Id}$.

301 See id at 92 n 6 (Marshall dissenting) ("As a matter of law, I seriously question whether simple English usage permits 'undue hardship' to be interpreted to mean 'more than de minimis cost."'). See also Adeyeye v Heartland Sweeteners, LLC, 721 F3d 444, 455 (7th Cir 2013) (observing that, by its plain language, "Title VII requires proof not of minor inconveniences but of hardship, and 'undue' hardship at that").

302 Hardison, 432 US at 84.

303 Letter from James Madison to Edward Livingston (July 10, 1822), in Gaillard Hut, ed, 9 The Writings of James Madison 1819-1836 100 (G.P. Putnam's Sons 1910). 
provisions limiting the right to free exercise to "actions that were 'peaceable' or that would not disturb the 'peace' or safety' of the state." ${ }^{04}$ The same basic idea appears repeatedly in Founding-era arguments about free exercise in the courts. ${ }^{305}$ And in terms of modern doctrine, that traditional limitation is most clearly analogous to the requirement-made explicit in statutes like RFRA - that an accommodation ought to be denied when applying the law to a claimant is the least restrictive means of furthering a compelling governmental interest.

Viewing the compelling interest test as the outer boundary for even for accommodations that relieve genuine burdens on religious practice makes sense for several reasons. First, it grounds the inquiry about disproportionate accommodations in historical practice. As a general matter, attempts to weigh burdens on religious practice against other kinds of interests suffer from an obvious difficulty-namely, the lack of a shared baseline. ${ }^{306}$ We simply lack a common measure for weighing the importance of practicing one's religion against other important concerns. The compelling interest test deals with that problem by overruling the legislature's power to grant accommodations in only the most extreme cases-cases in which the law at issue lies outside the traditional pattern of religious accommodation and thus cannot be seen as simply one more policy choice by the legislature.

Second, viewing the compelling interest test as the key to identifying disproportionate accommodations provides a sensible way of pinpointing illegitimate attempts to reward religious conformity. As we have observed, religious accommodations are clearly designed to protect a constitutional interest in free

304 McConnell, 103 Harv L Rev at 1461 (cited in note 1). To be sure, the precise meaning of these provisions has been the subject of intense debate. Compare Hamburger, 60 Geo Wash L Rev at 918-21 (cited in note 1) (arguing that these provisos in state constitutions implied that government could "deny religious freedom, not merely in the event of violence or force, but, more generally, upon the occurrence of illegal actions"), with Michael W. McConnell, Freedom from Persecution or Protection of the Rights of Conscience?: A Critique of Justice Scalia's Historical Arguments in City of Boerne v. Flores, 39 Wm \& Mary L Rev 819, 841-46 (1998) (arguing that Professor Philip Hamburger's interpretation cannot be squared with the text and drafting history of numerous state constitutions).

305 See McConnell, 103 Harv L Rev at 1503-05 (cited in note 1) (describing several of these court cases)

306 See Michael W. McConnell, Accommodation of Religion: An Update and a Response to the Critics, 60 Geo Wash L Rev 685, 705 (1992) (suggesting that such inquiries suffer from "the problem of comparing apples and oranges"). 
exercise whether the Free Exercise Clause strictly requires them or not. Yet the constitutional claims most closely analogous to that interest-namely, claims under the Free Speech Clause and the Equal Protection Clause-are also limited by the strict scrutiny inquiry as a matter of course. Viewing religious accommodations as bounded by these same standards suggests that government may adjust benefits and burdens to protect religious interests only as far (but no further) than the law protects other kinds of analogous constitutional rights. And in this way, it guarantees that accommodations are not just a pretext for rewarding religious behavior.

To be sure, there is more to be said. But at the very least, the basic point should be clear. Far from being indifferent to the costs of accommodation, the Establishment Clause takes them into account. But in separating permissible accommodations from impermissible ones, the key question is not whether an accommodation produces "harm." Rather, the question is whether an accommodation aims at inducing religious conformity by offering unjustified rewards.

\section{B. Other Considerations}

Let's return to the initial objection. The most obvious argument against my proposal that the Establishment Clause is best seen as a ban on government-induced religious conformity is that such a proposal does not account for the costs of accommodation. But that objection fails. Properly understood, the Establishment Clause ban on government-induced conformity includes not only attempts to entice citizens toward religion but also attempts to use accommodations as a pretext for rewarding groups of citizens who have already chosen to conform. More specifically, the Establishment Clause prohibits accommodations that offer benefits to religious claimants far outstripping any supposed burden on private free exercise as well as accommodations that command burden-shifting so disproportionate that the inference of unjustified favoritism is undeniable. When a law commands those things, the Establishment Clause clearly prohibits it.

But does that explanation really go far enough? For instance, although it is rare, accommodations do sometimes authorize significant harms that might not be prohibited by the compelling interest test. To use one example that I find particularly troubling, a nontrivial number of states exempt parents 
from child neglect prosecutions if they fail to seek basic medical treatment for their children for religious reasons. ${ }^{307}$ Yet enforcing those laws against every unwilling parent may not actually be mandated by the strict scrutiny inquiry, primarily because in many cases there will be a less restrictive alternative: a state could merely require religious parents to report the situation and provide treatment directly. ${ }^{308}$ In situations like these, even the strict scrutiny limitation may leave us with unsatisfying results.

Moreover, even assuming that the Establishment Clause limits disproportionate accommodations in the ways I suggest, the question about how certain kinds of conflicts ought to be analyzed under the strict scrutiny test can itself be a matter of vigorous disagreement. For example, the question of how this inquiry relates to claims for exemptions from public accommodations laws continues to divide scholars-even those deeply committed to eradicating discrimination. ${ }^{309}$ And as someone who supports both same-sex marriage and religious freedom, it seems clear to me that both sides of that debate have a point. Repeated denials of service $d o$ work a profound and significant harm-and one that is not reducible to material considerations like the opportunity to obtain the service elsewhere. ${ }^{310}$ At the same time, denying exemptions can also be profoundly damaging, forcing religious individuals to endure financial ruin or worse, and often in urban areas where they may already face

307 See, for example, Ind Code $\S 35-46-1-4(c)(2)$; NH Rev Stat Ann § 639:3; NY Penal Law § 260.15; Utah Code Ann § 76-5-109(6); Idaho Code Ann § 18-1501(4).

308 Compare, for example, Ind Code $\S 35-46-1-4$ (lacking any such requirement), with Minn Stat $\S 626.556(\mathrm{~g})(5)$ (providing an exemption from prosecution for child neglect when a person "depends upon spiritual means or prayer for treatment or care of disease," but requiring that such persons "report if a lack of medical care may cause serious danger to the child's health").

309 Compare, for example, Andrew Koppelman, Gay Rights, Religious Accommodations, and the Purposes of Antidiscrimination Law, 88 S Cal L Rev 619, 652 (2015) (arguing that dignitary harm is real and serious but that "the human costs of refusing accommodation are [also] serious" and sometimes justify exemptions), with NeJaime and Siegel, 124 Yale L J at 2580 (cited in note 23) (arguing that government's burden under strict scrutiny is usually satisfied when granting an accommodation would "inflict ... dignitary harm on those the statute is designed to protect").

310 See, for example, Roberts v United States Jaycees, 468 US 609, 625 (1984) (noting that discrimination can "deprive[] persons of their individual dignity" and inflict "stigmatizing injury"). See also Koppelman, 88 S Cal L Rev at 645 \& n 127 (cited in note 309) (documenting studies linking experiences of discriminatory treatment to negative impacts on mental and physical health among LGBTQ people). 
significant hostility. ${ }^{311}$ In those contexts, weighing the strength of the government interest can be difficult.

Providing answers to these questions would require a far more extensive discussion than can be offered here. Even without definitively resolving these issues, however, there are a few things we can say. The first is that, as a matter of actual practice, judges are extremely squeamish about commanding accommodations that involve significant harm to others. Legislatures might be willing to grant carte blanche exemptions from child neglect laws, vaccination requirements, and the like. But judges presented with those same claims under RFRA and similar laws almost never do.312 And indeed, that aversion is so strong that even the majority in Hobby Lobby could not bring itself to grant an exemption without effectively suggesting that the government "pick up the tab" and pay for the contraception, although nothing in RFRA actually mandated that result. ${ }^{313}$ To be sure, there may be outliers. But the extant evidence suggests that, by and large, when judges are empowered to protect the public interest, they do not do so lightly.

But there is also a second, equally important point. A judge faced with an accommodation claim under RFRA or similar statutes might ultimately conclude that the government lacks a compelling interest in enforcing a law or possesses a less restrictive means of furthering its interest. But that judgment does not invest courts with the final word on harm. Accommodations are ordinary laws. And like all other kinds of legislation, they are responsive to the popular will. They can be revised, limited, amended, or repealed. And the real-world evidence clearly demonstrates that this fact provides an additional and exceedingly powerful limit on the excesses religious accommodations

311 See, for example, Thomas C. Berg, Minority Religions and the Religion Clauses, 82 Wash U L Q 919, 945 (2004) (describing repeated efforts of New York-area public school officials "to exclude evangelical groups from meeting in the schools on the same terms as other voluntary groups"). See also Berg, 38 Harv J L \& Gender at 112 (cited in note 77) (noting recent polling suggesting that American voters now view evangelical Christians substantially less favorably than gays and lesbians).

312 See, for example, Workman v Mingo County Board of Education, 419 Fed Appx 348, 353-54 (4th Cir 2011) (denying a religious exemption from requirement that children be vaccinated to attend public school); Sherr v Northport-East Northport Union Free School District, 672 F Supp 81, 99 (EDNY 1987) (same); People v Hodges, 10 Cal App 4th Supp 20, 30-33 (1992) (denying a religious exemption from laws requiring reporting of known child abuse).

313 Hobby Lobby, $134 \mathrm{~S} \mathrm{Ct}$ at 2787 (Ginsburg dissenting). 
sometimes threaten, especially in cases involving public accommodations or LGBTQ rights.

Consider just a few of ways that political majorities have shaped or revised religious accommodations to soften some of the harder edges. Long before Hobby Lobby, legislatures in Pennsylvania and Louisiana limited their state RFRAs to apply only to nonprofit organizations. ${ }^{314}$ Those limitations have invited some confusion due to drafting problems, ${ }^{315}$ but they do have an obvious upside. If the concern is that accommodations risk giving businesses rather than churches or religious individuals the power to seek exemptions, that limitation takes care of the problem.

Or consider another strategy that has already been implemented in two very red states. Texas and Missouri both have state RFRAs that provide powerful protections for religious minorities. Yet voters in both states drew limits by making those RFRAs inapplicable to lawsuits involving civil rights laws. ${ }^{316}$ Those limits might stand in some tension with the purpose of religious accommodation laws by stacking the deck against especially unpopular religious claimants. But they could also be seen as simply clarifying that the people of Texas and Missouri believe that the government's interest in enforcing its civil rights laws is per se compelling. And that is a choice that the citizens of those states are undoubtedly empowered to make.

A third strategy accomplishes the same end but through slightly different means. Recall the firestorm in Indiana a few years ago about its newly passed RFRA. ${ }^{317}$ Critics of the law labeled it as a Jim Crow-style assault on LGBTQ rights because it explicitly applied to lawsuits brought by private parties, which by implication included suits brought under various public accommodations laws. ${ }^{318}$ The likelihood that any judge would actually validate a RFRA defense in such lawsuits was

314 See $71 \mathrm{~Pa}$ Stat Ann $\S 2403$ (defining "person" as "[a]n individual or a church, association of churches or other religious order, body or institution which qualifies for exemption from taxation"); 13 La Stat Ann § 5234(1) (same).

315 See Lund, Keeping Hobby Lobby in Perspective at 303-04 n 79 (cited in note 65) (explaining that the statutes invite significant confusion about whether they apply to religious schools and other nonprofits because such entities are not always eligible for tax-exempt status under the Internal Revenue Code).

316 See Tex Civ Prac and Remedies Code Ann $§ 110.011$; Mo Ann Stat $§ 1.307(2)$.

317 For a reminder, see Robertson and Pérez-Peña, Bills on Religious Freedom (cited in note 5).

318 See, for example, Tim Cook, Pro-discrimination "Religious Freedom" Laws Are Dangerous (Wash Post, Mar 29, 2015), archived at http://perma.cc/59YP-492B. 
disputed. ${ }^{319}$ But in the end, Indiana's representatives responded by amending its RFRA to exclude discrimination lawsuits from its reach, including those involving claims of discrimination based on sexual orientation or gender identity. ${ }^{320}$

People will differ as to whether these policy choices strike the correct balance between religious freedom and other important concerns. Some will say that they leave religious dissenters without adequate protection. Others will say that they don't go far enough in validating LGBTQ rights or employee protections. But the fact that people will disagree over how harms ought to be distributed is precisely the point. Speaking honestly, I think the Court was wrong to read the Free Exercise Clause as narrowly as it did in Smith and offload many decisions about religious exemptions to legislatures, where the risk of majoritarian bias is high. But whatever one thinks about that issue, one advantage of religious accommodation statutes is that they allow democratic majorities greater flexibility in how their commands will be implemented. And indeed, the evidence is fairly clear that, when it comes to the most controversial questions, political majorities have been exceedingly active in exercising that judgment.

\section{CONCLUSION}

Ours is a particularly crucial moment in the story of American religious liberty. For many important periods in our history, religious accommodation has been a laudable feature of the American experience. But in the wake of Hobby Lobby, we are now asking ourselves whether the cases in which religious accommodation and the culture war collide are sufficient reason to rethink our tradition.

In large measure, whether we will choose to retain or abandon robust religious accommodation laws will depend on whether there is willingness left-among progressives, but more

319 See Letter from Douglas Laycock, Robert E. Scott Distinguished Professor of Law, University of Virginia School of Law, to Brent Steele, Chair of the Judiciary Committee, Indiana Senate *5 (Feb 3, 2015), archived at http://perma.cc/NK6K-4LG7 (arguing that "[p]rotecting Americans from discrimination is generally a compelling interest, and few claims to exemption from anti-discrimination laws are likely to succeed").

320 See Ind Code $\S 34-13-9-0.7$. The law applies to numerous municipalities within Indiana that protect sexual orientation and gender identity through local ordinance. See Indiana: LGBT Non-discrimination in the States (Freedom for All Americans, Feb 7, 2018), archived at http://perma.cc/YR85-VHRC (listing municipalities in Indiana that provide such protections). 
importantly among conservatives-to see accommodation as something more than a symbolic weapon in the culture war. Indeed, the fate of religious accommodation as a practice may well depend on whether we can find ways to preserve the role of accommodations in protecting religious minorities without running roughshod over other important interests-especially those surrounding nondiscrimination and LGBTQ rights.

In the meantime, however, we do well to resist certain temptations. Justice Oliver Wendell Holmes famously remarked that "hard cases make bad law." ${ }_{221}$ We ought to heed his advice, especially when interpreting the Establishment Clause. The idea that the Establishment Clause prohibits "harmful" accommodations might sound appealing, especially when we are thinking about culture war issues. But it is ultimately unworkable as a legal rule and is at odds with our tradition and the best of our practices. The debate over religious accommodations will be resolved sooner or later, and probably in a way that leaves purists on both sides unsatisfied. But however that happens, it is to our benefit to develop an interpretation of the Establishment Clause that is faithful to history and sensible in light of precedent.

The Establishment Clause is not a cure-all for the problems sometimes accompanying religious accommodation. Rather, it is a guarantee that government can't use its power to control the religious lives of its citizens. As such, Establishment Clause limits on accommodation-like accommodations themselvesare about furthering freedom for everyone, religious or not. They ensure that, whether one chooses to practice a religion or refrain from practicing one, the choice to do so is really one's own. And in that way, they preserve religious freedom, a freedom that has always has been, in James Madison's words, "the glory of our country." 322

321 Northern Securities Co v United States, 193 US 197, 400 (1904) (Holmes dissenting).

3222 Annals of Congress 1871 (Dec 22, 1790) ("It is the glory of our country ... that a more sacred regard to the rights of mankind is preserved than has heretofore been known.”). 